\title{
HIMMELI v1.0: HelsinkI Model of MEthane buiLd-up and emIssion for peatlands
}

\author{
Maarit Raivonen $^{1}$, Sampo Smolander ${ }^{1,2}$, Leif Backman ${ }^{3}$, Jouni Susiluoto ${ }^{3,4}$, Tuula Aalto ${ }^{3}$, Tiina Markkanen ${ }^{3}$, \\ Jarmo Mäkelä ${ }^{3}$, Janne Rinne ${ }^{5}$, Olli Peltola ${ }^{1}$, Mika Aurela ${ }^{3}$, Annalea Lohila ${ }^{3}$, Marin Tomasic ${ }^{1}$, Xuefei Li ${ }^{1}$, \\ Tuula Larmola $^{6}$, Sari Juutinen ${ }^{7}$, Eeva-Stiina Tuittila ${ }^{8}$, Martin Heimann ${ }^{1,9}$, Sanna Sevanto ${ }^{10}$, Thomas Kleinen ${ }^{11}$, \\ Victor Brovkin $^{11}$, and Timo Vesala ${ }^{1,12}$ \\ ${ }^{1}$ Division of Atmospheric Sciences, Department of Physics, University of Helsinki, P.O. Box 68, \\ 00014 Helsinki, Finland \\ ${ }^{2}$ Princeton Environmental Institute, Guyot Hall, Princeton University, Princeton, NJ 08544, USA \\ ${ }^{3}$ Climate research, Finnish Meteorological Institute, P.O. Box 503, 00101 Helsinki, Finland \\ ${ }^{4}$ Lappeenranta University of Technology, School of Science, 53850 Lappeenranta, Finland \\ ${ }^{5}$ Department of Physical Geography and Ecosystem Science, Lund University, Sölvegatan 12, \\ 22362 Lund, Sweden \\ ${ }^{6}$ Natural Resources Institute Finland (Luke), Latokartanonkaari 9, 00790 Helsinki, Finland \\ ${ }^{7}$ Department of Environmental Sciences, University of Helsinki, Viikinkaari 1, 00790 Helsinki, Finland \\ ${ }^{8}$ School of Forest Sciences, University of Eastern Finland, P.O. Box 111, 80770 Joensuu, Finland \\ ${ }^{9}$ Max Planck Institute for Biogeochemistry, 07745 Jena, Germany \\ ${ }^{10}$ Earth and Environmental Sciences Division, Los Alamos National Laboratory, Bikini Atoll Rd. \\ MS J535, Los Alamos, NM 87545, USA \\ ${ }^{11}$ Max Planck Institute for Meteorology, Bundesstr, 53, 20146, Hamburg, Germany \\ ${ }^{12}$ Department of Forest Sciences, University of Helsinki, P.O. Box 27, 00014 Helsinki, Finland
}

Correspondence: Maarit Raivonen (maarit.raivonen@helsinki.fi)

Received: 2 March 2017 - Discussion started: 27 March 2017

Revised: 25 October 2017 - Accepted: 2 November 2017 - Published: 22 December 2017

\begin{abstract}
Wetlands are one of the most significant natural sources of methane $\left(\mathrm{CH}_{4}\right)$ to the atmosphere. They emit $\mathrm{CH}_{4}$ because decomposition of soil organic matter in waterlogged anoxic conditions produces $\mathrm{CH}_{4}$, in addition to carbon dioxide $\left(\mathrm{CO}_{2}\right)$. Production of $\mathrm{CH}_{4}$ and how much of it escapes to the atmosphere depend on a multitude of environmental drivers. Models simulating the processes leading to $\mathrm{CH}_{4}$ emissions are thus needed for upscaling observations to estimate present $\mathrm{CH}_{4}$ emissions and for producing scenarios of future atmospheric $\mathrm{CH}_{4}$ concentrations. Aiming at a $\mathrm{CH}_{4}$ model that can be added to models describing peatland carbon cycling, we composed a model called HIMMELI that describes $\mathrm{CH}_{4}$ build-up in and emissions from peatland soils. It is not a full peatland carbon cycle model but it requires the rate of anoxic soil respiration as input. Driven by soil temperature, leaf area index (LAI) of aerenchymatous peat-
\end{abstract}

land vegetation, and water table depth (WTD), it simulates the concentrations and transport of $\mathrm{CH}_{4}, \mathrm{CO}_{2}$, and oxygen $\left(\mathrm{O}_{2}\right)$ in a layered one-dimensional peat column. Here, we present the HIMMELI model structure and results of tests on the model sensitivity to the input data and to the description of the peat column (peat depth and layer thickness), and demonstrate that HIMMELI outputs realistic fluxes by comparing modeled and measured fluxes at two peatland sites. As HIMMELI describes only the $\mathrm{CH}_{4}$-related processes, not the full carbon cycle, our analysis revealed mechanisms and dependencies that may remain hidden when testing $\mathrm{CH}_{4}$ models connected to complete peatland carbon models, which is usually the case. Our results indicated that (1) the model is flexible and robust and thus suitable for different environments; (2) the simulated $\mathrm{CH}_{4}$ emissions largely depend on the prescribed rate of anoxic respiration; (3) the sensitivity of 
the total $\mathrm{CH}_{4}$ emission to other input variables is mainly mediated via the concentrations of dissolved gases, in particular, the $\mathrm{O}_{2}$ concentrations that affect the $\mathrm{CH}_{4}$ production and oxidation rates; (4) with given input respiration, the peat column description does not significantly affect the simulated $\mathrm{CH}_{4}$ emissions in this model version.

\section{Introduction}

Methane $\left(\mathrm{CH}_{4}\right)$ is an important greenhouse gas, atmospheric concentrations of which have increased by more than $250 \%$ since preindustrial times, inducing the second largest radiative forcing among well-mixed greenhouse gases (Myhre et al., 2013). Wetlands are the largest single natural $\mathrm{CH}_{4}$ source to the atmosphere and their $\mathrm{CH}_{4}$ emissions respond to changes in climatic conditions, which can be seen at global level (Bridgham et al., 2013; Turetsky et al., 2014). In order to upscale observed $\mathrm{CH}_{4}$ fluxes and to produce realistic scenarios for the future atmospheric greenhouse gas concentrations, it is essential to know how wetland $\mathrm{CH}_{4}$ emissions respond to climatic variables. Modeling these responses has been active in recent years (e.g., Wania et al., 2010; Riley et al., 2011; Melton et al., 2013; Schuldt et al., 2013; Grant et al., 2015).

Freshwater wetlands emit $\mathrm{CH}_{4}$ from decomposition of soil organic matter because oxygen $\left(\mathrm{O}_{2}\right)$ concentrations in their water-saturated soils are low. Anoxic decomposition of soil organic matter is partly carried out by methanogenic microbes that produce $\mathrm{CH}_{4}$, so the decomposition process releases both $\mathrm{CH}_{4}$ and carbon dioxide $\left(\mathrm{CO}_{2}\right)$ (Nilsson and Öquist, 2009). Anoxia has also forced vascular wetland plants to develop techniques to get $\mathrm{O}_{2}$ to their roots that extend to the inundated soil layers. For example, sedge species from genera Carex and Eriophorum, common in northern fen-type peatlands, have aerenchyma, special tissue with airfilled spaces that allows diffusion of $\mathrm{O}_{2}$ from the atmosphere to the roots (Moog and Brüggemann, 1998). Some aquatic plants transport $\mathrm{O}_{2}$ actively through the aerenchyma with pressurized throughflow (Brix et al., 1996). As a byproduct, these mechanisms also transport $\mathrm{CH}_{4}$ to the atmosphere (Morrissey et al., 1993; Brix et al., 1996). In addition to transfer via plants, $\mathrm{CH}_{4}$ is known to be emitted from peatlands as ebullition, i.e., release of $\mathrm{CH}_{4}$ bubbles into the atmosphere, and by diffusion through the peat column. $\mathrm{CH}_{4}$ can also be consumed in the soil by methanotrophic bacteria that derive their energy by oxidizing $\mathrm{CH}_{4}$ to $\mathrm{CO}_{2}$.

The three transport mechanisms and the $\mathrm{CH}_{4}$ oxidation have been implemented in many peatland models in which the peat column is divided into layers and physically based formulations simulate the carbon processes in them (see a review in Xu et al., 2016). Many of them have features adopted from previous models - for instance, the Walter and Heimann model of $\mathrm{CH}_{4}$ production and emission (Walter and
Heimann, 2000; Walter et al., 1996) is frequently utilized but often the implementations include specific modifications. Some of the models also simulate the $\mathrm{O}_{2}$ transport and the simulated $\mathrm{O}_{2}$ concentrations affect the $\mathrm{CH}_{4}$ processes. These models have been used in multiple studies (e.g., Berrittella and van Huissteden, 2009, 2011; Khvorostianov et al., 2008; Ringeval et al., 2011; Melton et al., 2013; Budishchev et al., 2014; Cresto Aleina et al., 2015; Grant et al., 2015), and some are referred to in the assessment report of the Intergovernmental Panel on Climate Change (IPCC; Ciais et al., 2013). These models have different approaches in simulating the production of $\mathrm{CH}_{4}$, ranging from separating distinct heterotrophic microbial communities (Grant and Roulet, 2002) to taking a constant fraction of the simulated heterotrophic soil respiration (Riley et al., 2011). After that, the transport models essentially take care of determining which portion of the $\mathrm{CH}_{4}$ is oxidized and which is released to the atmosphere.

As $\mathrm{CH}_{4}$ transport and oxidation can be simulated separately from other soil carbon processes, without the need to feed back to the main soil model; they can form a separate module. There are soil models that simulate anoxic respiration (e.g., Clark et al., 2011; Schuldt et al., 2013) and so this would be their interface to a $\mathrm{CH}_{4}$ module. For this kind of use, we composed HIMMELI, the HelsinkI Model of MEthane buiLd-up and emIssion, which is a module that simulates only the processes related to transport and oxidation of $\mathrm{CH}_{4}$. It takes the rate of anoxic peat respiration as input, defined here as the rate of anoxic decomposition of organic compounds in peatland soil, and computes the subsequent $\mathrm{CH}_{4}$ emission by simulating the transport and build-up of $\mathrm{CH}_{4}, \mathrm{O}_{2}$, and $\mathrm{CO}_{2}$ in the soil, as well as the $\mathrm{CH}_{4}$ oxidation rate that depends on the prevailing $\mathrm{O}_{2}$ concentrations. HIMMELI is driven with soil temperature, water table depth, and the leaf area index of the gas-transporting plant canopy.

HIMMELI does not bring any new processes as such into the $\mathrm{CH}_{4}$ model world and it utilizes process descriptions largely adopted from earlier models (e.g., Arah and Stephen, 1998; Tang et al., 2010; Wania et al., 2010). However, it is among the most complete models considering the transport of compounds. According to Xu et al. (2016), there are only five models that simulate all vertically resolved biogeochemistry, $\mathrm{O}_{2}$ availability to $\mathrm{CH}_{4}$ oxidation, and three pathways of $\mathrm{CH}_{4}$ transport. Of these, the Xu model (Xu et al., 2007), CLM-Microbe (Xu et al., 2014), and VISIT (Ito and Inatomi, 2012) do not explicitly simulate $\mathrm{O}_{2}$ transport between the atmosphere and peat. On the other hand, LPJ-WhyMe (Wania et al., 2010), a revised multi-substance version of TEM (Tang et al., 2010), ecosys (version in Grant and Roulet, 2002), and a recent model by Kaiser et al. (2017) - not included in the list by Xu et al. (2016) - do simulate all these. HIMMELI also simulates $\mathrm{CO}_{2}$ transport via all three transport pathways. This is not a common feature in $\mathrm{CH}_{4}$ models: to our knowledge, only the multi-substance version of TEM (Tang et al., 2010), ecosys (Grant and Roulet, 2002), and the Segers model (Segers and Leffelaar, 2001a-c) included that. 
The novelty of HIMMELI is that it has been developed independent of a full peatland carbon model, with the ambition to obtain a robust and flexible model that can be easily used as a tool within different environments as, for instance, its peat column structure is not fixed.

Sensitivity analyses on the complete peatland models have been presented, mostly concentrating on the sensitivity to model parameters (e.g., Berrittella and Huissteden, 2009, 2011; Tang et al., 2010; Wania et al., 2010; Zhu et al., 2014), but we are not aware of any studies which would have analyzed the sensitivity of the $\mathrm{CH}_{4}$ models as such to driving variables. This kind of analysis is, however, important because a $\mathrm{CH}_{4}$ module can form a considerable part of a peatland carbon model and studying it alone may reveal dependencies that affect the output $\mathrm{CH}_{4}$ emissions but are not seen in sensitivity tests on full carbon models. Because HIMMELI includes components similar to earlier $\mathrm{CH}_{4}$ models, the results of the sensitivity analysis should be interesting for the modeling community.

In the present work, we (a) define key factors for $\mathrm{CH}_{4}$ transport and oxidation, (b) describe the model, (c) analyze its dynamics and sensitivity of output fluxes to input data in steady-state tests, (d) analyze the model sensitivity to the description of the peat column by running the model for a Finnish peatland flux measurement site (Siikaneva) (Rinne et al., 2007), and (e) demonstrate with data from Siikaneva and another site (Lompolojänkkä) (Aurela et al., 2009) that, combined with realistic input, HIMMELI output $\mathrm{CH}_{4}$ fluxes are realistic compared to measurements, which is not so evident if looking only at the mechanistic sensitivity tests.

\section{Key factors for $\mathrm{CH}_{4}$ transport and oxidation}

The rate of $\mathrm{CH}_{4}$ production in peat has been found to be controlled by peat and substrate quality, temperature, and $\mathrm{pH}$ (Valentine et al., 1994; Bergman et al., 1999; Reiche et al., 2010). However, the final emissions depend on how much $\mathrm{CH}_{4}$ is consumed by methanotrophic bacteria. This can be up to $100 \%$ of the $\mathrm{CH}_{4}$ produced (Whalen, 2005; Fritz et al., 2011). The probability of a $\mathrm{CH}_{4}$ molecule to get oxidized is thought to depend on which pathway it takes to escape from the soil since the conditions are suitable for methanotrophy mostly in oxic peat layers. Ebullition may bypass this oxidative zone (Coulthard et al., 2009) and although methanotrophs are also found in some wetland plant roots (King, 1994), oxidation can largely be avoided by moving through the plants. Several studies have shown that the $\mathrm{CH}_{4}$ emissions decrease clearly when the gas-transporting plants are removed from a site, indicating that aerenchymatous vegetation is an effective transport route for $\mathrm{CH}_{4}$ (Waddington et al., 1996; King et al., 1998; Green and Baird, 2012).

Roots of sedges, particularly those of Carex species, extend deep to the soil (Shaver and Cutler, 1979; Saarinen, 1996). Therefore, they have a large contact surface with the anoxic peat. The area of root surface permeable to gases was the most important factor controlling the $\mathrm{CH}_{4}$ flux in Juncus effusus, another aerenchymatous species, and this permeable surface is concentrated in fine roots and the tips of coarser roots (Hennenberg et al., 2012). According to Reid et al. (2015), the rate for root-mediated gas transport in $P$. australis and Spartina patens increased during the growing season, indicating increase of permeable root surface area or aerenchyma along the summer. Thus, the growth of the plants seems to affect their gas transport capacity. Isotopic studies have shown that passive diffusion down the concentration gradient dominates the $\mathrm{CH}_{4}$ transport in sedges (Chanton and Whiting, 1993; Popp et al., 1999), and Moog and Brüggemann (1998) also demonstrated that diffusion is a sufficient explanation for the supply of $\mathrm{O}_{2}$ to the roots of Carex species. There are, however, contrasting findings about where the main resistance for the diffusive $\mathrm{CH}_{4}$ flux lies. Kelker and Chanton (1997) suggested it is belowground, at the soil-root or root-shoot boundaries, and that Carex releases $\mathrm{CH}_{4}$ not through the leaf blades (and stomata) but from the point where the leaves bundle. This would be similar to rice (Oryza sativa), Menyanthes trifoliata, and $J$. effusus that release $\mathrm{CH}_{4}$ from the stem or leaf sheath, possibly through micropores, not stomata (Nouchi et al., 1990; Macdonald et al., 1998; Hennenberg et al., 2012). However, in the studies by Schimel (1995) and Morrissey et al. (1993), $\mathrm{CH}_{4}$ seemed to exit the sedges through the leaf blades and stomata, and this would thus form the main resistance for the flux in the plant. Diurnal variation of the $\mathrm{CH}_{4}$ emissions could indicate stomatal control but clear diurnal patterns have not been observed (Rinne et al., 2007; Jackowicz-Korczyński et al., 2010); the maximum emissions may even occur at night (Mikkelä et al., 1995; Waddington et al., 1996; Juutinen et al., 2004). On the other hand, possible diurnal changes in $\mathrm{O}_{2}$ diffusion to the rhizosphere may be reflected in the $\mathrm{CH}_{4}$ fluxes since $\mathrm{O}_{2}$ concentration affects the rate of $\mathrm{CH}_{4}$ oxidation (Thomas et al., 1996), and diurnal changes in the $\mathrm{CH}_{4}$ substrate input from the photosynthesizing vegetation may affect $\mathrm{CH}_{4}$ production (Mikkelä et al., 1995).

Gas ebullition occurs, in principle, when the concentration of a dissolved gas reaches saturation, but in practice $\mathrm{CH}_{4}$ ebullition has been observed in wetlands already with concentrations below saturation (Baird et al., 2004; Kellner et al., 2006; Waddington et al., 2009; Bon et al., 2014). Other gases increase the gas pressure and soil particles and impurities lower the energy barrier for gas nucleation. The $\mathrm{CH}_{4}$ content in ebullitive gas fluxes has been estimated to be 45 to $60 \%$ (Glaser et al., 2004; Tokida et al., 2005; Kellner et al., 2006) and the rest consists mainly of $\mathrm{O}_{2}, \mathrm{CO}_{2}$, and nitrogen $\left(\mathrm{N}_{2}\right)$ (Tokida et al., 2005). The volumetric gas content (VGC) in the peat has been observed to be approximately 10 to $15 \%$ (Kellner et al., 2006; Tokida et al., 2007; Waddington et al., 2009), indicating that all the formed gas does not escape the soil. Ebullition events seem to be affected by atmospheric pressure. When the pressure declines, bubble vol- 
ume increases and the solubility of gases decreases, allowing more gases to accumulate in the bubbles. Consequently, their buoyancy may overcome the forces that resist their movement and ebullition occurs (Tokida et al., 2007; Waddington et al., 2009). Increasing pressure, by contrast, may enhance the bubble mobility through the peat by causing bubble size to decrease (Comas et al., 2011). Movement of bubbles also depends on the peat structure that varies along the peat column as well as within and between peatlands, due to differences in peat composition and decomposition status (Rezanezhad et al., 2016). The shallow, less decomposed peat has more space for the bubbles, while the more decomposed deeper peat layers are tighter packed (Comas et al., 2011).

Properties of the peat column also affect the diffusion of $\mathrm{CH}_{4}$ and $\mathrm{O}_{2}$ in the air- and water-filled peat pores. Porosity of the soil, i.e., the fraction of the soil volume that is taken up by the pore space, as well as interconnectivity, pore shape, and size distribution determine the rate of diffusion. Different descriptions of the dependency of diffusion coefficient on the soil porosity or tortuosity have been presented (Millington, 1959; Collin and Rasmuson, 1988; Staunton, 2008). The porosity of peat soils is generally high, at least $80 \%$ (Mitsch and Gosselink, 2007). Therefore, peat does not hinder the diffusion as much as many other soil types. In models, the peat column is commonly considered in a simplified way, assuming that the water table depth (WTD) forms a border below which the peat is saturated with water and above which peat pores are air filled. However, in reality, the division is not this strict, as VGC can be a considerable fraction of the total volume below the WTD, for instance, due to the gas production in the peat (Waddington et al., 2009), and the peat can be wet above the WTD if the peat pores retain water when the WTD drops (Estop-Aragonés et al., 2012; Fan et al., 2014). Diffusion through the peat column is thought to be a minor component in the total $\mathrm{CH}_{4}$ emissions of a peatland when gas-transporting vegetation is present at the site (Walter et al., 1996; Lai, 2009), because the diffusion coefficient in water is approximately 4 orders of magnitude lower than in gas (Staunton, 2008) and because the probability of $\mathrm{CH}_{4}$ being consumed by methanotrophs is higher in the peat, especially when the WTD is low (Estop-Aragonés et al., 2012).

Methanotrophic bacteria occur in all soils, not only wetlands, and methanotrophy in upland soils is the largest biogenic sink of atmospheric $\mathrm{CH}_{4}$ (Ciais et al., 2013). Rate of the $\mathrm{CH}_{4}$ oxidation reaction depends on the concentrations of both $\mathrm{CH}_{4}$ and $\mathrm{O}_{2}$ (Watson et al., 1997) and since $\mathrm{CH}_{4}$ oxidation is a biochemical reaction, the rate is also limited by factors that affect the microbial activity, such as temperature (Whalen and Reeburgh, 1996). When the WTD is low, the $\mathrm{O}_{2}$ concentrations in the top peat layers are high, favoring $\mathrm{CH}_{4}$ oxidation (Moore et al., 2011; Estop-Aragonés et al., 2012). However, there can be anoxic areas above the WTD (Silins and Rothwell, 1999; Fan et al., 2014) and the $\mathrm{O}_{2}$ transported down by plant roots provides conditions suitable for methanotrophy also in the inundated peat layers (Fritz et al., 2011).

\section{Model and methods}

\subsection{Model description}

\subsubsection{General}

The model (Fig. 1) simulates microbial and transport processes that take place in a one-dimensional peat column, keeping track on the concentration profiles of $\mathrm{CH}_{4}, \mathrm{O}_{2}$, and $\mathrm{CO}_{2}$. The output is fluxes of $\mathrm{CH}_{4}, \mathrm{O}_{2}$, and $\mathrm{CO}_{2}$ between the soil and the atmosphere, with the possibility to separate the contributions of the three different transport routes, as well as to extract the amount of oxidized $\mathrm{CH}_{4}$. The required input and the model output are explained in more detail within the model code package that is provided as a Supplement to this article. So far, the model does not consider freezing and ice, but it is valid when peat water is not frozen. Parameter values used in the present study (Table 1) were based on literature values (see Sect. 3.2) and the aim was to have physically sound parameter values. However, if using HIMMELI in large-scale $\mathrm{CH}_{4}$ modeling, the model possibly needs to be recalibrated.

The model is driven with

- peat temperature, $T(\mathrm{~K})$;

- leaf area index of aerenchymatous gas-transporting vegetation, LAI $\left(\mathrm{m}^{2} \mathrm{~m}^{-2}\right)$;

- water table depth, WTD (m); and

- anaerobic carbon decomposition rate, i.e., the rate of anoxic respiration for the area of the peatland, $V_{\mathrm{anR}}$ $\left(\mathrm{mol} \mathrm{m} \mathrm{s}^{-2} \mathrm{~s}^{-1}\right)$.

The reaction-diffusion equations governing the concentrations of the three compounds $\left(\mathrm{CH}_{4}, \mathrm{O}_{2}\right.$, and $\left.\mathrm{CO}_{2}\right)$ at depth $z$ are (Eqs. 1-3)

$$
\begin{aligned}
& \frac{\partial}{\partial t} C_{\mathrm{CH}_{4}}(t, z)= \\
& \quad-\frac{\partial}{\partial z} F_{\mathrm{CH}_{4}}-Q_{\mathrm{plt}, \mathrm{CH}_{4}}-Q_{\mathrm{ebu}, \mathrm{CH}_{4}}+R_{\mathrm{CH}_{4}}-R_{\mathrm{O}},
\end{aligned}
$$

$$
\begin{aligned}
& \frac{\partial}{\partial t} C_{\mathrm{O}_{2}}(t, z)= \\
& \quad-\frac{\partial}{\partial z} F_{\mathrm{O}_{2}}-Q_{\mathrm{plt}, \mathrm{O}_{2}}-Q_{\mathrm{ebu}, \mathrm{O}_{2}}-R_{\mathrm{aR}}-2 R_{\mathrm{O}},
\end{aligned}
$$

$$
\begin{aligned}
& \frac{\partial}{\partial t} C_{\mathrm{CO}_{2}}(t, z)=-\frac{\partial}{\partial z} F_{\mathrm{CO}_{2}}-Q_{\mathrm{plt}, \mathrm{CO}_{2}}-Q_{\mathrm{ebu}, \mathrm{CO}_{2}} \\
& \quad+\left(R_{\mathrm{anR}}-R_{\mathrm{CH}_{4}}\right)+R_{\mathrm{O}}+R_{\mathrm{aR}} .
\end{aligned}
$$

Here, $F_{\mathrm{CH}_{4}}, F_{\mathrm{O}_{2}}$, and $F_{\mathrm{CO}_{2}}$ are the diffusive fluxes in the peat (in water below the WTD and in air above it; see Sect. 3.1.8); 
Table 1. Model parameters and their values. The reference is given in the cases where the value is directly from one study; otherwise, the parameter value is discussed in Sect. 3.2.

\begin{tabular}{|c|c|c|c|}
\hline Symbol & Definition & Value & Reference \\
\hline$\lambda$ & decay length (in root distribution) & 0.2517 & Wania et al. (2010) \\
\hline$f_{\mathrm{m}}$ & fraction of anaerobic respiration becoming methane & 0.5 & \\
\hline$V_{\mathrm{R}}$ & potential rate of aerobic respiration at $10^{\circ} \mathrm{C}\left(\mathrm{mol} \mathrm{m}^{-3} \mathrm{~s}^{-1}\right)$ & $1 \times 10^{-5}$ & \\
\hline$K_{\mathrm{R}}$ & Michaelis constant for aerobic respiration reaction $\left(\mathrm{mol} \mathrm{m}^{-3}\right)$ & 0.02 & \\
\hline$V_{\mathrm{O}}$ & potential oxidation rate at $10^{\circ} \mathrm{C}\left(\mathrm{mol} \mathrm{m}^{-3} \mathrm{~s}^{-1}\right)$ & $1 \times 10^{-5}$ & \\
\hline$K_{\mathrm{O}_{2}}$ & Michaelis constant for $\mathrm{O}_{2}$ in oxidation $\left(\mathrm{mol} \mathrm{m}^{-3}\right)$ & 0.03 & \\
\hline$K_{\mathrm{CH}_{4}}$ & Michaelis constant for $\mathrm{CH}_{4}$ in oxidation $\left(\mathrm{mol} \mathrm{m}^{-3}\right)$ & 0.03 & \\
\hline$\Delta E_{\mathrm{R}}$ & activation energy of aerobic respiration $\left(\mathrm{J} \mathrm{mol}^{-1}\right)$ & 50000 & Stephen et al. (1998) \\
\hline$\Delta E_{\mathrm{O}}$ & activation energy of oxidation $\left(\mathrm{J} \mathrm{mol}^{-1}\right)$ & 50000 & \\
\hline$T_{\varnothing}$ & reference temperature for oxidation and aerobic respiration $(\mathrm{K})$ & 283 & \\
\hline$k$ & time constant of ebullition $\left(\mathrm{s}^{-1}\right)$ & $1 / 1800$ & \\
\hline$a_{\mathrm{mA}}$ & root ending area per root dry biomass $\left(\mathrm{m}^{2} \mathrm{~kg}^{-1}\right)$ & 0.085 & Stephen et al. (1998) \\
\hline$\tau$ & root tortuosity & 1.5 & Stephen et al. (1998) \\
\hline SLA & specific leaf area of gas-transporting plants $\left(\mathrm{m}^{2} \mathrm{~kg}\right)$ & 15 & \\
\hline$f_{\mathrm{D}, \mathrm{w}}$ & reduction factor for diffusion in water-filled peat & 0.8 & \\
\hline$f_{\mathrm{D}, \mathrm{a}}$ & reduction factor for diffusion in air-filled peat & 0.8 & \\
\hline$\eta$ & sensitivity of methanogenesis to oxygen $\left(\mathrm{m}^{3} \mathrm{~mol}^{-1}\right)$ & 400 & Arah and Stephen (1998) \\
\hline$\sigma$ & peat porosity & 0.85 & \\
\hline
\end{tabular}

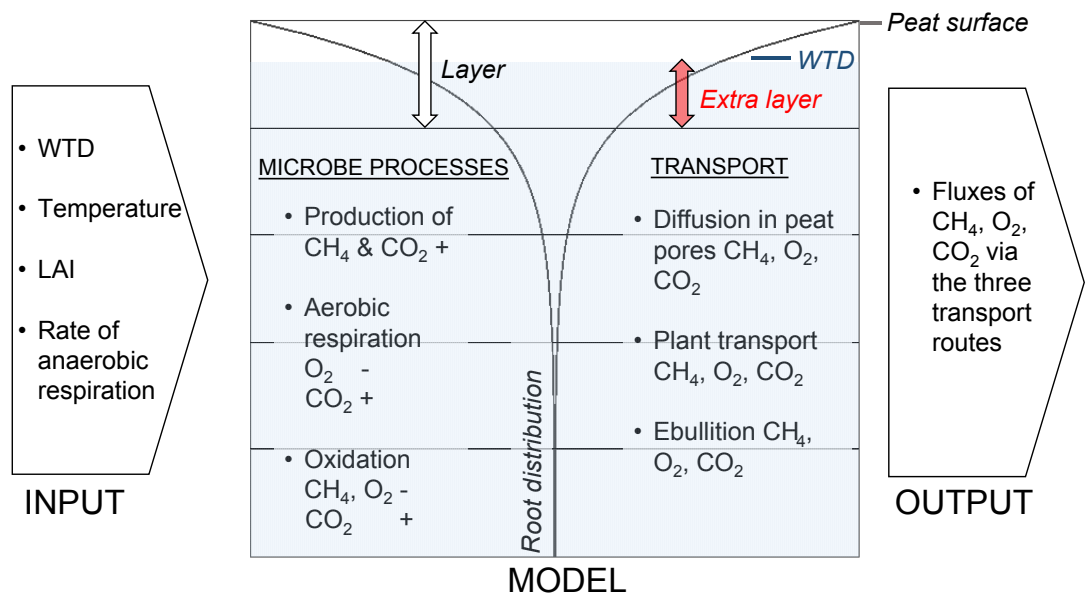

Figure 1. HIMMELI as a simplified schematic picture. The microbial and transport processes are simulated in a vertically layered onedimensional peat column in which roots of aerenchymatous gas-transporting plants are distributed according to the exponential root distribution function. The input anoxic respiration is distributed along the root distribution. Input water table depth (WTD) determines the thickness of the possible extra layer that is introduced in the event the WTD does not match any of the fixed background layer borders. This ensures that all the simulated layers are either completely water filled or air filled. The + sign shows that the compound is produced in the microbial process and the - sign means consumption of the compound.

$Q_{\mathrm{plt}, X}$ and $Q_{\mathrm{ebu}, X}$ are the transport rates of gas $X$ between peat and atmosphere via plant roots and by ebullition, respectively; $R_{\mathrm{CH}_{4}}$ is the $\mathrm{CH}_{4}$ production rate; $R_{\mathrm{anR}}$ is the rate of anaerobic respiration; $R_{\mathrm{aR}}$ is the rate of aerobic respiration; and $R_{\mathrm{O}}$ is the $\mathrm{CH}_{4}$ oxidation rate.

The model has been developed principally using a daily time step for input and output, as our main target has been to use it with models that provide daily input. However, we also tested running HIMMELI on a shorter time step (Sect. 3.3.2).
The internal time step is determined by the turnover time of $\mathrm{CH}_{4}$ and $\mathrm{O}_{2}$ concentrations in the peat. It is assumed that the longest usable time step is half of the turnover time. The differential equations are solved simultaneously using the fourth-order Runge-Kutta method. 


\subsubsection{Peat geometry, root distribution, and movement of water}

The model basically describes a one-dimensional, vertically layered peat column. Peat depth and layer thicknesses are not fixed but different setups can be used. The only limitation for the layer structure is that if the peat thickness exceeds $2 \mathrm{~m}$, there has to be a layer border exactly at the $2 \mathrm{~m}$ depth, because of how the roots are treated in the model. The layering below $2 \mathrm{~m}$ must start from that depth.

In the model, WTD is a strict divider of the peat into water-filled and air-filled parts. This has been implemented by adding an extra layer in the pre-described layer composition (Fig. 1). Its thickness is adjusted so that the water surface is always exactly at the interface between the two layers. This approach enables using the exact given WTD as input. Only in the case that the boundary of the extra layer would be closer than $1 \mathrm{~cm}$ to a boundary of the background layering, the WTD is rounded to this nearest permanent layer boundary. Strict division of the peat to air-filled and water-filled parts is a simplification since anoxic sites can occur above the WTD (Estop-Aragonés et al., 2012). However, as in sitelevel and larger-scale simulations, even an observation-based WTD is an approximate value over peatland areas, and we consider the strict division to anoxic and oxic parts a robust approach.

In HIMMELI, the water level can also be above the peat surface, and in this case an extra water layer is located above the peat surface. In nature, wind mixing can affect the concentrations of different compounds in free water but this is not considered in the model. This simplification is justified, as there often is vegetation that decreases the wind mixing via affecting wind speed.

Changing WTD essentially means addition or removal of water to/from the peat column. At the same time, the masses of $\mathrm{CH}_{4}, \mathrm{O}_{2}$, and $\mathrm{CO}_{2}$ need to be conserved. In the case of rising WTD, the $\mathrm{CH}_{4}, \mathrm{O}_{2}$, and $\mathrm{CO}_{2}$ that were in the air-filled layers are dissolved in the water until the concentrations in the newly water-filled layers reach the solubility limit with the previous air concentrations. The excess gas is pushed upwards to the lowest air-filled layer (or to the atmosphere). In the case of lowering WTD, the $\mathrm{CH}_{4}, \mathrm{O}_{2}$, and $\mathrm{CO}_{2}$ of the previously water-filled layers are introduced into the air-filled layers replacing them. This can cause exceptionally high or low fluxes and concentrations in some layers, but these even out fast in relation to the daily time step, mainly through diffusion.

An essential role is played by the vertical distribution of plant roots since that determines how the input anoxic respiration and the gas-transporting root mass is distributed vertically. The formulation has been adopted from Wania et al. (2010):

$$
f_{\text {root }}(z)=C e^{-z / \lambda} \text {, }
$$

where $f_{\text {root }}(z)$ is the fraction of roots at depth $z, \lambda$ is a root depth distribution decay parameter, and $C$ is a normalizing constant defined so that the sum of root fractions equals 1 (Eq. 5):

$$
\int_{0}^{z_{\max }} f_{\text {root }}(z) \mathrm{d} z=1 .
$$

The maximum depth that the roots are assumed to reach is $2 \mathrm{~m}$ (Saarinen, 1996). If the peat depth exceeds $2 \mathrm{~m}$, there is a rootless zone at the bottom. The value of $C$ depends on the peat thickness and geometry of the current peat column, and it is calculated at each time step, so the root distribution can adjust to changing peat depth.

\subsection{3 $\mathrm{CH}_{4}$ production}

The input anaerobic respiration $\left(V_{\mathrm{anR}}\right)$ is distributed vertically along the root distribution in the anaerobic peat layers below the WTD (Eq. 6):

$R_{\mathrm{anR}}(z)=\frac{V_{\mathrm{anR}}}{\mathrm{d} z} f_{\text {root, an }}(z)$.

Here, $R_{\mathrm{anR}}(z)\left(\mathrm{mol} \mathrm{m}^{-3} \mathrm{~s}^{-1}\right)$ is the rate of anoxic respiration at depth $z, f_{\text {root,an }}(z)$ refers to the ratio of root mass at depth $z$ to the total root mass of the anaerobic zone, and $\mathrm{d} z(\mathrm{~m})$ is the layer thickness. In the case that peat depth exceeds the maximum rooting depth of $2 \mathrm{~m}$, the model calculates what would be the anaerobic respiration rate at the bottom root layer if all the input carbon was allocated in the rooting zone, then allocates $50 \%$ of that in the rootless layers, and the remainder is redistributed to the rooting zone.

This choice of distributing the anoxic respiration with root mass (as opposed to distributing it, e.g., evenly across the peat column) was motivated by the fact that recently fixed carbon, such as root exudates, seems to be the main source of $\mathrm{CH}_{4}$. For instance, according to Oikawa et al. (2017), less than $5 \%$ of $\mathrm{CO}_{2}$ and $\mathrm{CH}_{4}$ emissions originate from soils below $50 \mathrm{~cm}$ in flooded peatlands. However, in the case that HIMMELI is used in a study where it is essential to simulate the different carbon sources and distribute $\mathrm{CH}_{4}$ production in a different way, it is relatively easy to modify the code so that this becomes possible.

$\mathrm{CH}_{4}$ production rate $R_{\mathrm{CH}_{4}}\left(\mathrm{~mol} \mathrm{~m}^{-3} \mathrm{~s}^{-1}\right)$ in a peat layer at depth $z$ is calculated as a fixed fraction $\left(f_{\mathrm{m}}\right)$ of $R_{\mathrm{anR}}$ but the rate may be inhibited by dissolved $\mathrm{O}_{2}$, following Arah and Stephen (1998) (Eq. 7):

$$
R_{\mathrm{CH}_{4}}(z)=f_{\mathrm{m}} R_{\mathrm{anR}}(z) \frac{1}{1+\eta C_{\mathrm{O}_{2}}(z)},
$$

where $\eta$ is a parameter reflecting the sensitivity of methanogenesis to $\mathrm{O}_{2}$ inhibition. The $\mathrm{CH}_{4}$ production rate in conditions with no $\mathrm{O}_{2}$, i.e., $C_{\mathrm{O}_{2}}$ is zero, is called potential methane production (PMP) in this paper. The rest of the anaerobic respiration $\left(R_{\mathrm{anR}}-R_{\mathrm{CH}_{4}}\right)$ produces $\mathrm{CO}_{2}$. HIMMELI does not 
include electron acceptors other than $\mathrm{O}_{2}$ since their concentrations can be expected to depend on site characteristics; it would thus be difficult to estimate them and these estimates would not necessarily improve the accuracy of the model. However, including known factors that affect $\mathrm{CH}_{4}$ production, such as the alternative electron acceptors, is important and could possibly be a way to take into account site differences in future model versions.

\subsubsection{Aerobic respiration}

All the $\mathrm{O}_{2}$ in the peat is not consumed by the methanotrophs but other aerobic microbe processes like aerobic peat respiration also require $\mathrm{O}_{2}$. This $\mathrm{O}_{2}$ consumption rate that affects the $\mathrm{O}_{2}$ availability of $\mathrm{CH}_{4}$ oxidation is estimated with a Michaelis-Menten model, following Arah and Stephen (1998) (Eq. 8):

$R_{\mathrm{aR}}(z, T)=V_{\mathrm{R}}(T) \frac{C_{\mathrm{O}_{2}}(z)}{K_{\mathrm{R}}+C_{\mathrm{O}_{2}}(z)}$,

where $R_{\mathrm{aR}}\left(\mathrm{mol} \mathrm{m}^{-3} \mathrm{~s}^{-1}\right)$ is the rate of aerobic respiration at temperature $T$ at depth $z, V_{\mathrm{R}}\left(\mathrm{mol} \mathrm{m}^{-3} \mathrm{~s}^{-1}\right)$ is the potential rate of respiration at temperature $T$, and $K_{\mathrm{R}}\left(\mathrm{mol} \mathrm{m}^{-3}\right)$ is the Michaelis constant for the reaction. This reaction produces $1 \mathrm{~mol}$ of $\mathrm{CO}_{2}$ per each mole of $\mathrm{O}_{2}$ consumed.

\subsection{5 $\mathrm{CH}_{4}$ oxidation}

The rate of $\mathrm{CH}_{4}$ oxidation is assumed to follow the dualsubstrate Michaelis-Menten kinetics (Arah and Stephen, 1998) (Eq. 9):

$R_{\mathrm{O}}(z T)=V_{\mathrm{O}}(T) \frac{C_{\mathrm{O}_{2}}(z)}{K_{\mathrm{O}_{2}}+C_{\mathrm{O}_{2}}(z)} \times \frac{C_{\mathrm{CH}_{4}}(z)}{K_{\mathrm{CH}_{4}}+C_{\mathrm{CH}_{4}}(z)}$,

where $R_{\mathrm{O}}\left(\mathrm{mol} \mathrm{m}^{-3} \mathrm{~s}^{-1}\right)$ is the oxidation rate at temperature $T$ at depth $z, V_{\mathrm{O}}\left(\mathrm{mol} \mathrm{m}^{-3} \mathrm{~s}^{-1}\right)$ is the potential oxidation rate at temperature T, and $K_{\mathrm{O}_{2}}\left(\mathrm{~mol} \mathrm{~m}^{-3}\right)$ and $K_{\mathrm{CH}_{4}}\left(\mathrm{~mol} \mathrm{~m}^{-3}\right)$ are the Michaelis constants for $\mathrm{O}_{2}$ and $\mathrm{CH}_{4}$, respectively. Each $\mathrm{CH}_{4}$ mol oxidized consumes 2 moles of $\mathrm{O}_{2}$ and produces $1 \mathrm{~mol} \mathrm{CO}_{2}$.

\subsubsection{Temperature dependency of microbial reactions}

The reaction rates of oxidation and aerobic respiration depend on temperature following the form of the Arrhenius equation (Eq. 10):

$V(T)=V_{\varnothing} \exp \left(\frac{\Delta E}{R}\left(\frac{1}{T_{\varnothing}}-\frac{1}{T}\right)\right)$,

where $V(T)$ refers to the rate of oxidation or aerobic respiration at temperature $T, V_{\varnothing}\left(\mathrm{mol} \mathrm{m}^{-3} \mathrm{~s}^{-1}\right)$ is the reaction rate at the reference temperature $T_{\varnothing}(\mathrm{K}), R\left(\mathrm{~J} \mathrm{~mol}^{-1} \mathrm{~K}^{-1}\right)$ is the gas constant, and $\Delta E\left(\mathrm{~J} \mathrm{~mol}^{-1}\right)$ the activation energy of the reaction.

\subsubsection{Ebullition}

The ebullition model takes into account concentrations of $\mathrm{CH}_{4}, \mathrm{CO}_{2}, \mathrm{O}_{2}$, and $\mathrm{N}_{2}$ and uses the sum of their partial pressures to determine when ebullition occurs. This approach was previously used by Tang et al. (2010). In HIMMELI, ebullition is the only process that takes $\mathrm{N}_{2}$ into account. We assume $\mathrm{N}_{2}$ is always in equilibrium with the atmospheric concentration and so its partial pressure in the peat is always $78 \%$ of the atmospheric pressure. The model computes the solubilities of $\mathrm{CH}_{4}, \mathrm{CO}_{2}$, and $\mathrm{O}_{2}$ in water using the dimensionless Henry's law coefficient (see Appendix A for formulation; Sander, 2015).

If the sum of the partial pressures pp ( $\mathrm{Pa}$ ) of the dissolved $\mathrm{CH}_{4}, \mathrm{CO}_{2}, \mathrm{O}_{2}$, and $\mathrm{N}_{2}\left(\mathrm{pp}_{X}\right)$ exceeds the sum of the atmospheric and hydrostatic pressures $\left(P_{\text {atm }}\right.$ and $P_{\text {hyd }}$, respectively) (Eq. 11) such that

$\sum_{X} \operatorname{pp}_{X}(z)>P_{\text {atm }}+P_{\text {hyd }}(z)$,

ebullition occurs. The model first computes the fraction of ebullition, $f_{\mathrm{e}}$ (Eq. 12):

$f_{\mathrm{e}}(z)=\frac{\sum_{X} \mathrm{pp}_{X}(z)-\left(P_{\mathrm{atm}}+P_{\mathrm{hyd}}(z)\right)}{\sum_{X} \mathrm{pp}_{X}(z)}$,

and this fraction of each gas is removed, expressed as a rate by introducing time constant $k\left(\mathrm{~s}^{-1}\right)$ in the equation. The ebullition rate $Q_{\mathrm{ebu}, X}\left(\mathrm{~mol} \mathrm{~m}^{-3} \mathrm{~s}^{-1}\right)$ of compound $X$ from a soil layer at depth $z$ thus is (Eq. 13)

$Q_{\mathrm{ebu}, X}(z)=-k \frac{f_{\mathrm{e}}(z) \mathrm{pp}_{X} \sigma}{R T}$,

where $\sigma$ is peat porosity. Ebullition only occurs in the waterfilled peat. If the WTD is below the peat surface, the ebullited gases are transferred into the lowest air-filled soil layer and they continue from there via diffusion in the peat or in plant roots. Otherwise, the ebullition is released directly into the atmosphere.

In reality, bubble movement in porous media is a highly complex problem that depends on the fine-scale structure of the media. After a bubble has been formed, there are several processes that take place before the bubble reaches the surface and contributes to the $\mathrm{CH}_{4}$ flux to the atmosphere. For instance, the bubbles need to traverse through the peat column and on the way they interact with the surrounding pore water and hence alter the $\mathrm{CH}_{4}$ concentration gradients. These processes are still missing from most of the peatland $\mathrm{CH}_{4}$ models (Xu et al., 2016), including HIMMELI. This is most likely because relatively little is known about bubble movement in peat and how to describe it accurately in models, although there are some attempts to model this process (Ramirez et al., 2015). Different ebullition modeling approaches were compared by Peltola et al. (2017). 


\subsubsection{Diffusion in the peat}

Simulation of diffusion in the porous water-filled or air-filled peat takes into account the reduction in the diffusivity compared with pure water or air (see, e.g., Iiyama and Hasegawa, 2005). The diffusion coefficients used in this study are listed in Appendix A. The effective diffusivities in the porous peat $\left(D_{\text {peat,w }}\right.$ and $D_{\text {peat, a }} ; \mathrm{m}^{2} \mathrm{~s}^{-1}$ ) are calculated by multiplying the free-water or free-air diffusivities by (dimensionless) constant reduction factors $f_{\mathrm{D}, \mathrm{w}}$ and $f_{\mathrm{D}, \mathrm{a}}$ (Eqs. 14 and 15$)$.

$D_{\text {peat }, \mathrm{w}}=f_{\mathrm{D}, \mathrm{w}} D_{\mathrm{w}}$

$D_{\text {peat, } \mathrm{a}}=f_{\mathrm{D}, \mathrm{a}} D_{\mathrm{a}}$

The diffusion $\left(F_{X} ; \mathrm{mol} \mathrm{m}^{-2} \mathrm{~s}^{-1}\right)$ of compound $X$ between layers is calculated using a difference equation that is set up between the center points $(i-1$ and $i)$ of the layers (Eq. 16):

$F_{i-1, i}=D_{\text {peat }, \mathrm{X}} \frac{\left(C_{X, i-1}-C_{X, i}\right)}{\mathrm{d} x}$.

Here, $\mathrm{d} x(\mathrm{~m})$ is the distance between points $i-1$ and $i$, and $C_{X, i-1}$ and $C_{X, i}$ are the concentrations at these layers. The surface layer at the water-air interface is assumed to be in equilibrium with the gas-phase concentrations according to Henry's law. The diffusion flux across the water-air interface is then calculated from the difference in concentration between the layer center points and water-air interface as shown by Bird et al. (1960). The final equation for the flux of compound $X$ at the interface becomes (Eq. 17)

$F_{X}=\frac{2 D_{\text {peat }, \mathrm{w}, X} D_{\text {peat,a, } X}}{D_{\text {peat }, \mathrm{a}, X}+D_{\text {peat }, \mathrm{w}, X} k_{\mathrm{H}, X}} \frac{C_{X, \mathrm{w}}-k_{\mathrm{H}, X} C_{X, \mathrm{a}}}{\mathrm{d} x}$,

where $D_{\text {peat,w, } X}$ and $D_{\text {peat,a, } X}$ are the diffusion coefficients in the water and air-filled layers, $k_{\mathrm{H}, X}$ is Henry's law coefficient in dimensionless form (Appendix A), and $C_{X \text {,w }}$ and $C_{X, \mathrm{a}}\left(\mathrm{mol} \mathrm{m}^{-3}\right)$ are the concentrations of compound $X$ in the water-filled and air-filled layers, respectively.

\subsubsection{Plant transport}

Formulation of plant transport rate $Q_{\mathrm{plt}, X}$ of compound $X$ $\left(\mathrm{mol} \mathrm{m}^{-3} \mathrm{~s}^{-1}\right)$ is similar to many other peatland models in that it describes diffusion in air-filled tubes that represent aerenchymatous plant roots. We employ the formulation from Stephen et al. (1998) that uses the density of crosssectional area of root endings as the variable expressing the abundance of gas-transporting vegetation (Eq. 18):

$Q_{\mathrm{plt}, X}(z)=\frac{\varepsilon_{\mathrm{r}}(z) D_{\text {peat }, \mathrm{a}, \mathrm{X}}}{\tau} \frac{C_{X}(z, t)-C_{\mathrm{atm}, X}}{z}$.

Here, $\varepsilon_{\mathrm{r}}$ is the density of cross-sectional area of root endings at depth $z\left(\mathrm{~m}^{2} \mathrm{~m}^{-3}\right)$ and $\tau$ is root tortuosity. To account for the porous structure of aerenchyma (Colmer, 2003), HIMMELI uses the same value as in air-filled peat, $D_{\text {peat,a }}$ $\left(\mathrm{m}^{2} \mathrm{~s}^{-1}\right)$, as the diffusion coefficient inside roots. It is averaged over the temperatures of the different layers between each depth $z$ that the roots go through. $\varepsilon_{\text {r }}$ follows the root distribution and it depends on the LAI of the vegetation via (Eq. 19)

$\varepsilon_{\mathrm{r}}(z)=a_{\mathrm{mA}} \frac{f_{\text {root }}(z)}{\mathrm{d} z} \frac{\mathrm{LAI}}{\mathrm{SLA}}$,

where $a_{\mathrm{mA}}$ expresses the cross-sectional area of root endings per root dry biomass $\left(\mathrm{m}^{2} \mathrm{~kg}^{-1}\right), \mathrm{d} z$ is the layer thickness $(\mathrm{m})$, and SLA is the specific leaf area $\left(\mathrm{m}^{2} \mathrm{~kg}^{-1}\right)$. Root mass is thus assumed to equal the aboveground biomass.

\subsection{Model parameterization}

Table 1 lists the parameter values used in this study, as well as the literature references of cases where the value was taken directly from one study. Here, we go through the parameter values that were based on several papers or some calculation. The parameterization of HIMMELI has been analyzed in more detail in a separate study by Susiluoto et al. (2017).

The $\mathrm{CH}_{4}$ oxidation model has four parameters: $K_{\mathrm{O}_{2}}$, $K_{\mathrm{CH}_{4}}, V_{\mathrm{O}}$, and $\Delta E_{\mathrm{O}}$. Watson et al. (1997) used $K_{\mathrm{O}_{2}}$ of $0.032 \mathrm{~mol} \mathrm{~m}^{-3}$, and we chose to use this value rounded to $0.03 \mathrm{~mol} \mathrm{~m}^{-3}$. For $K_{\mathrm{CH}_{4}}$, we found several literature values: $0.001 \mathrm{~mol} \mathrm{~m}^{-3}$ in Dunfield et al. (1993), 0.045 and 0.058 in Watson et al. (1997), and 0.001 to 0.045 in the review by Segers (1998). We chose an average of these, i.e., $0.03 \mathrm{~mol} \mathrm{~m}^{-3}$. Dunfield et al. (1993) found that the activation energy of methanotrophy is 20 to $80 \mathrm{~kJ} \mathrm{~mol}^{-1}$, and also here we chose the average, $50 \mathrm{~kJ} \mathrm{~mol}^{-1}$. Using this in the Arrhenius equation (Eq. 10) fit well with the $V_{\mathrm{O}}$ values reported by Watson et al. (1997) and Dunfield et al. (1993) that were $28 \mu \mathrm{mol} \mathrm{m} \mathrm{m}^{-3} \mathrm{~s}^{-1}$ at $25^{\circ} \mathrm{C}$ and 12 to $15 \mu \mathrm{mol} \mathrm{m}^{-3} \mathrm{~s}^{-1}$ at $15^{\circ} \mathrm{C}$, respectively, and thus we set $V_{\mathrm{O}}$ to $10 \mu \mathrm{mol} \mathrm{m}{ }^{-3} \mathrm{~s}^{-1}$ at the reference temperature $T_{\sigma}, 283 \mathrm{~K}$.

The model of aerobic respiration has three parameters: $K_{\mathrm{R}}, V_{\mathrm{R}}$, and $\Delta E_{\mathrm{R}}$. Watson et al. (1997) used $K_{\mathrm{R}}$ of $0.022 \mathrm{~mol} \mathrm{~m}^{-3}$, and liyama et al. (2012) found in their review a $K_{\mathrm{R}}$ range of approximately 0.002 to $0.02 \mathrm{~mol} \mathrm{~m}^{-3}$. On this basis, we set this to $0.02 \mathrm{~mol} \mathrm{~m}^{-3}$. Stephen et al. (1998) used $\Delta E_{\mathrm{R}}$ value of $50 \mathrm{~kJ} \mathrm{~mol}^{-1}$, which was supported by Lloyd and Taylor (1994); hence, we also used this value for the activation energy. $V_{R}$ was based on observed respiration rates on the Siikaneva peatland measurement site (Sect. 3.4.1) that we used in model testing. Respiration rate derived from the mean temperature, mean WTD, and mean $\mathrm{CO}_{2}$ emission rate observed in July 2005 at Siikaneva (Aurela et al., 2007) was $16 \mu \mathrm{mol} \mathrm{m}{ }^{-3} \mathrm{~s}^{-1}$ at $16.5^{\circ} \mathrm{C}$. Using the $\Delta E_{\mathrm{R}}$ mentioned above in Eq. (10), $V_{\mathrm{R}}$ at the reference temperature $T_{\sigma}$ of $283 \mathrm{~K}$ was approximately $10 \mu \mathrm{mol} \mathrm{m} \mathrm{m}^{-3} \mathrm{~s}^{-1}$.

The fraction of anaerobic respiration becoming $\mathrm{CH}_{4}, f_{\mathrm{m}}$, affects $\mathrm{CH}_{4}$ generation and therefore also the emission rate directly. According to Nilsson and Öquist (2009), theoretically, the $\mathrm{CH}_{4}$ yield from terminal mineralization of soil 
organic matter in optimal methanogenic conditions ranges from 0 to $70 \%$, being around $50 \%$ when carbohydrates are mineralized. Their literature review showed, however, dominance of $\mathrm{CO}_{2}$ : the observed $\mathrm{CO}_{2} / \mathrm{CH}_{4}$ quotient in anoxic incubations had varied from 0.5 to 36000 with median value in a filtered data set being around 6. HIMMELI does not simulate different $\mathrm{CH}_{4}$ production pathways or methanogen groups but uses only this one parameter. We chose to use the conservative ratio $50 / 50$, i.e., $f_{\mathrm{m}}$ of 0.5 .

Peat porosity $\sigma$ was based on the review by Rezanezhad et al. (2016) that gave a range of 71 to $95 \%$. We chose to use an average value of $85 \%$. Reduction factors for the water and air diffusion coefficients in peat, $f_{\mathrm{D}, \mathrm{w}}$ and $f_{\mathrm{D}, \mathrm{a}}$, were set by using the model by Millington and Quirk (1961) (Eq. 20):

$\frac{D_{\mathrm{S}}}{D_{0}}=\sigma^{\frac{3}{4}}$,

where $D_{\mathrm{S}}$ is the diffusion coefficient in soil and $D_{0}$ in free air. The resulting reduction factor was 0.80 . We do not know to what extent this applies also to diffusion in water; however, we used the same value for both $f_{\mathrm{D}, \mathrm{w}}$ and $f_{\mathrm{D}, \mathrm{a}}$.

SLA values for graminoids or sedges varied widely in literature. Raivonen et al. (2015) found that the SLA of sedges in one peatland site was $7 \mathrm{~m}^{2} \mathrm{~kg}^{-1}$, Poorter and De Jong (1999) reported the SLA of Carex species on a fen to be on average $15 \mathrm{~m}^{2} \mathrm{~kg}^{-1}$, and Vile et al. (2005) gave $23 \mathrm{~m}^{2} \mathrm{~kg}^{-1}$ generally for graminoids. We decided to use an average, $15 \mathrm{~m}^{2} \mathrm{~kg}^{-1}$. Time constant for ebullition, $k$, was set to $1 / 1800 \mathrm{~s}$ based on model numerics; now, the half-life of the excess concentrations becomes longer than the usual internal time step.

\subsection{Model testing}

We analyzed HIMMELI's sensitivity to the driving input variables, length of time step, and the description of the peat column, i.e., peat column depth and layer thickness. The model sensitivity to input variables and time step length was analyzed using steady-state tests and transition tests (see Sect. 3.3.1 and 3.3.2). The effect of the peat column setup was analyzed by running HIMMELI with data from the Siikaneva peatland site with different peat column descriptions (Sect. 3.4.1). In addition, we compared the modeled $\mathrm{CH}_{4}$ fluxes to measured fluxes at Siikaneva and at another peatland site, Lompolojänkkä (Sect. 3.4.2), in order to demonstrate that when combined with realistic input, HIMMELI outputs realistic $\mathrm{CH}_{4}$ fluxes.

\subsubsection{Testing model sensitivity to input data}

The steady-state tests were conducted to study how sensitive the model is to the input data and to understand how the sensitivity depends on the modeled processes. We tested the model by running it into equilibrium with several different input value combinations, starting from empty concentration profiles of all the compounds. Specifically, we tested the sensitivity of the model to peat temperature, WTD, LAI (and corresponding root mass), and rate of anoxic respiration, by varying these one by one. Temperature was always constant throughout the soil profile in these experiments, unlike in the simulations of the peatland sites. We also conducted three transition tests to study the model response to changing WTD, temperature, and anoxic respiration rate. In those, the model was first equilibrated with one set of driver values and after that the WTD, peat temperature, or anoxic respiration was alternated. The different input combinations, details of the tests and their names are summarized in Tables 2 and 3.

The tests are labeled so that the first letter ( $T$ for temperature, W for WTD, L for LAI, and $R$ for respiration) tells which input varied and the rest shows the values of the constant input variables, with the simplification that W03 stands for WTD of $-0.3 \mathrm{~m}$. The transition test names just show the changing variables; Wtr stands for WTD transition, Ttr for temperature transition and Rtr for respiration transition. The input range for LAI was based on, e.g., Slevin et al. (2015) and range of anoxic respiration on, e.g., Scanlon and Moore (2000) and Szafranek-Nakonieczna and Stepniewska (2014).

In these mechanistic sensitivity tests, the anoxic respiration rate $\left(\mathrm{mol} \mathrm{m}^{-2} \mathrm{~s}^{-1}\right)$ was independent of temperature and WTD since the purpose was to analyze the sensitivity of the processes that HIMMELI simulates, and anoxic respiration is only input for HIMMELI. We did not want to set any dependency here since it would have meant, in practice, that the test results are valid only when the dependency is as we described it. In this way, we kept the tests more generic. The idea was to analyze how much and via what pathways the other driving variables (WTD, temperature, LAI) affect the output $\mathrm{CH}_{4}$ emission rate when the carbon input rate is constant. The input respiration was always allocated only to the inundated peat layers. Consequently, when the WTD varied, also the number of layers into which the anoxic respiration was allocated varied, although the total respiration rate of the peat column remained constant.

\subsubsection{Testing a time step of $30 \mathrm{~min}$}

In order to find out whether eliminating the diurnal temperature variation with the daily time step affects the modeled fluxes, we compared a model run done on a 30 min time step to a run done on the daily time step. We chose an arbitrary summer day, 1 July 2006, and took the soil and air temperature data measured at Siikaneva at 30 min intervals. All other input values were constant over the day in both runs. To avoid possible complications originating from the fact that the first and last temperatures of the chosen day differed by $3^{\circ}$ (air) and $0.5^{\circ}$ (top soil layer), we modified slightly the temperatures measured in the evening. We interpolated new values between the high afternoon temperatures and the new last temperature that was set to be close to the first measurement of the day (Fig. 2). We ran HIMMELI over 35000 days using 
Table 2. Summary of the steady-state sensitivity tests in which response of HIMMELI to different input combinations was analyzed.

\begin{tabular}{|c|c|c|c|c|}
\hline Test name & $T\left({ }^{\circ} \mathrm{C}\right)$ & WTD (m) & $\operatorname{LAI}\left(\mathrm{m}^{2} \mathrm{~m}^{-2}\right)$ & $\begin{array}{l}\text { Anoxic respiration } \\
\qquad\left(\mu \mathrm{mol} \mathrm{m}{ }^{-2} \mathrm{~s}^{-1}\right)\end{array}$ \\
\hline T_W0_L0_R1 & $5,10,20,25$ & 0 & 0 & 1 \\
\hline T_W0_L1_R1 & $5,10,20,25$ & 0 & 1 & 1 \\
\hline L_W0_T10_R1 & 10 & 0 & $0,0.5,1,2,3$ & 1 \\
\hline L_W03_T10_R1 & 10 & -0.3 & $0,0.5,1,2,3$ & 1 \\
\hline W_L0_T10_R1 & 10 & $-0.5,-0.3,-0.2,-0.1,0,0.05$ & 0 & 1 \\
\hline W_L1_T10_R1 & 10 & $-0.5,-0.3,-0.2,-0.1,0,0.05$ & 1 & 1 \\
\hline R_W0_L0_T10 & 10 & 0 & 0 & $0.01,0.1,0.5,1,5,10$ \\
\hline R_W0_L1_T10 & 10 & 0 & 1 & $0.01,0.1,0.5,1,5,10$ \\
\hline R_W03_L0_T10 & 10 & -0.3 & 0 & $0.01,0.1,0.5,1,5,10$ \\
\hline R_W03_L1_T10 & 10 & -0.3 & 1 & $0.01,0.1,0.5,1,5,10$ \\
\hline
\end{tabular}

Table 3. Summary of the transition tests on model sensitivity to input data and the input combinations used in the tests.

\begin{tabular}{lrrrr}
\hline Test name & $T\left({ }^{\circ} \mathrm{C}\right)$ & WTD $(\mathrm{m})$ & $\begin{array}{r}\text { LAI }\left(\mathrm{m}^{2} \mathrm{~m}^{-2}\right) \\
\text { Anoxic respiration } \\
\left(\mu \mathrm{mol} \mathrm{m}^{-2} \mathrm{~s}^{-1}\right)\end{array}$ & $\begin{array}{r}\text { An } \\
\text { Wtr_L1 }\end{array}$ \\
Wtr_L0 & 10 & $0,-0.2,-0.4,-0.2,0$ & 1 & 1 \\
\hline Rtr_W0_L1 & 10 & $0,-0.2,-0.4,-0.2,0$ & 0 & 1 \\
Rtr_W0_L0 & 10 & 0 & 0 & $0.5,1,2,1,0.5$ \\
\hline Ttr_W0_L1 & 10 & 0 & 1 & 1 \\
Ttr_W0_L0 & $10,12,14,12,10$ & 0 & 0 & 1 \\
\hline
\end{tabular}

first these data and a 30 min time step, then using the daily average of the temperatures and a $24 \mathrm{~h}$ time step. Within this time, the concentrations reached reasonable saturation. WTD was set to $-16 \mathrm{~cm}$ (the daily average WTD measured at Siikaneva on 1 July 2006), LAI was $1 \mathrm{~m}^{2} \mathrm{~m}^{-2}$, and the anoxic respiration rate was $1 \mu \mathrm{mol} \mathrm{m} \mathrm{m}^{-2} \mathrm{~s}^{-1}$.

\subsubsection{Testing model sensitivity to the description of the peat column}

We ran the model with a 7-year input data series from the Siikaneva fen and tested how sensitive the results are to peat depth and peat layer thicknesses. We used the same input anoxic respiration, WTD, and LAI for all the model runs. The only factor that changed slightly between the different setups was the soil temperature since the interpolated temperature profile always followed the layering. In these simulations, anoxic respiration was not constant but simulated (see Appendix B). The model spin-up was conducted by running the model through the entire 7-year time series of input data until the peat $\mathrm{CH}_{4}$ concentrations stabilized. The spinup time we used depended on the peat thickness, being up to 600 cycles in the case of $5 \mathrm{~m}$ peat.

We tested four peat depths $(1,2,3$, and $5 \mathrm{~m})$ using $0.2 \mathrm{~m}$ layer thickness in every case. In addition, we tested two

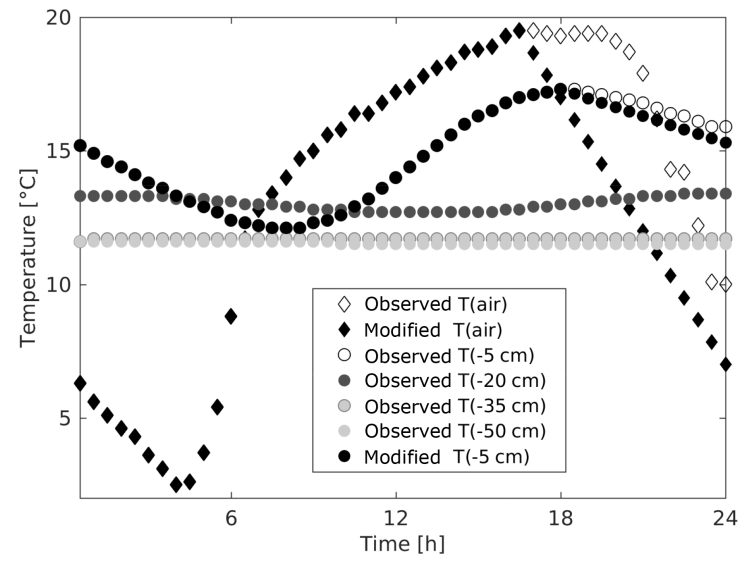

Figure 2. Daily variation of air and soil temperatures in the time step test. Observed temperatures are directly from measurement data, but in order to smooth the difference between the last and first temperatures of the day, we modified the afternoon temperatures as shown in the plot.

evenly spaced layerings, 0.1 and $0.2 \mathrm{~m}$, as well as one logarithmic layer structure, in a $2 \mathrm{~m}$ deep peat column. The logarithmic structure was based on the one used in the land surface model JSBACH (Ekici et al., 2014) and the layer thick- 
nesses from top to bottom were $0.06,0.13,0.26,0.52$, and $1.03 \mathrm{~m}$.

\subsubsection{Comparison of HIMMELI and measured $\mathrm{CH}_{4}$ fluxes in the Siikaneva and Lompolojänkkä sites}

In order to demonstrate that HIMMELI outputs realistic fluxes when run with realistic input (which is not so evident if looking only at the mechanistic sensitivity tests), we compared the modeled and measured $\mathrm{CH}_{4}$ fluxes on two sites, Siikaneva and Lompolojänkkä (Sect. 3.4) using anoxic respiration estimated for the sites as input. The purpose of this comparison also was a general evaluation of what is the significance of using HIMMELI compared to using (simulated) anoxic respiration rate directly as the basis of $\mathrm{CH}_{4}$ emission estimations.

\subsection{Peatland sites and data}

\subsubsection{Siikaneva site description}

The eddy covariance flux measurement site is located in Siikaneva in Ruovesi, southern Finland $\left(61^{\circ} 49^{\prime} \mathrm{N}, 24^{\circ} 11^{\prime} \mathrm{E}\right.$; 162 ma.s.l.) (Rinne et al., 2007). The site is a boreal oligotrophic fen where the vegetation is dominated by sedges (C. rostrata, C. limosa, E. vaginatum), Rannochrush (Scheuchzeria palustris), and peat mosses (Sphagnum balticum, S. majus, and $S$. papillosum). Peat depth at the measurement footprint is 2 to $4 \mathrm{~m}$. Annual mean temperature from 1971 to 2000 at a nearby weather station was $3.3^{\circ} \mathrm{C}$ and precipitation was $713 \mathrm{~mm}$ (Drebs et al., 2002). Siikaneva is a well-established site following the common standards and requirements for eddy covariance measurements, and its characteristics and representativeness of the data have been analyzed in several papers (Aurela et al., 2007; Rinne et al., 2007).

The measurement setup for $\mathrm{CH}_{4}$ fluxes consisted of an acoustic anemometer and a fast-response $\mathrm{CH}_{4}$ analyzer. The acoustic anemometer was Metek USA-1 during the whole measurement period, while there were changes in the methane analyzers. The $\mathrm{CH}_{4}$ analyzers used were the Campbell TGA-100 (2005 to 2007 and April 2010 to August 2010), Los Gatos RMT-200 (2008-2011) and Picarro G1301-f (April 2010 to October 2011). For $\mathrm{CO}_{2}$ and water vapor fluxes, a closed-path infrared absorption gas analyzer LI-7000 (LI-COR, Inc.) was used. The sonic anemometer and the intake for the $\mathrm{CH}_{4}$ analyzer were at $2.75 \mathrm{~m}$ from peat surface. The sample air taken to the TGA-100 was dried using a Nafion drier. For RMT-200 and G1301-f, sample air was not dried. The measurement setup for 2005 to 2007 has been described in detail by Aurela et al. (2007) and Rinne et al. (2007).

The flux data were post-processed using EddyUH software (Mammarella et al., 2016). The fluxes were calculated using block-averaging and sector-wise planar fitting. High- frequency losses were corrected by empirically determined transfer functions (Mammarella et al., 2009). For 2008 to 2011 , the dilution effect by water vapor was corrected with the Webb-Leuning-Pearman method (Webb et al., 1980), whereas for 2005 to 2007 this correction was not needed due to the usage of a drier in the sampling line.

\subsubsection{Lompolojänkkä site description}

The Lompolojänkkä measurement site is an open, nutrientrich sedge fen located in the aapa mire region of northwestern Finland (67 $59.832^{\prime} \mathrm{N}, 24^{\circ} 12.551^{\prime} \mathrm{E}$; $269 \mathrm{~m}$ a.s.1.). The vegetation layer is dominated by Betula nana, Menyanthes trifoliata, Salix lapponum, and Carex ssp. with a mean vegetation height of $40 \mathrm{~cm}$ and one-sided LAI of 1.3 . The moss cover on the ground is patchy (57\% coverage), consisting mainly of peat mosses (Sphagnum angustifolium, S. riparium, and S. fallax), and some brown mosses (Warnstorfia exannulata). The mean annual temperature of $-1.4{ }^{\circ} \mathrm{C}$ and precipitation of $484 \mathrm{~mm}$ have been measured at the nearest longterm weather station of Alamuonio $\left(67^{\circ} 58^{\prime} \mathrm{N}, 23^{\circ} 41^{\prime} \mathrm{E}\right)$ during the period 1971 to 2000 (Drebs et al., 2002).

The eddy covariance system used for measuring the vertical $\mathrm{CO}_{2}$ and $\mathrm{CH}_{4}$ fluxes included a USA-1 (Metek) three-axis sonic anemometer/thermometer, a closed-path LI7000 (LI-COR, Inc.) $\mathrm{CO}_{2} / \mathrm{H}_{2} \mathrm{O}$ analyzer, and RMT-200 (Los Gatos Research) $\mathrm{CH}_{4}$ analyzer. The measurement height was $3 \mathrm{~m}$ and the lengths of the inlet tubes for the LI-7000 and RMT-200 were 8 and $15 \mathrm{~m}$, respectively. The mouths of the inlet tubes were placed $15 \mathrm{~cm}$ below the sonic anemometer and flow rates of 5 to $6 \mathrm{~L} \mathrm{~min}^{-1}$ and $16 \mathrm{~L} \mathrm{~min}^{-1}$ were used for LI-7000 and RMT-200, respectively. Synthetic air with a zero $\mathrm{CO}_{2}$ concentration was used as the reference gas for LI7000. For more details of the eddy covariance measurement system, see Aurela et al. (2009).

Half-hour flux values were calculated using standard eddy covariance methods. The original $10 \mathrm{~Hz}$ data were block averaged, and a double rotation of the coordinate system was performed (McMillen, 1988). The time lag between the anemometer and gas analyzer signals, resulting from the transport through the inlet tube, was taken into account in the online calculations. An air density correction related to the sensible heat flux is not necessary for the present system (Rannik et al., 1997), but the corresponding correction related to the latent heat flux was made (Webb et al., 1980). Corrections for the systematic high-frequency flux loss due to the imperfect properties and setup of the sensors (insufficient response time, sensor separation, damping of the signal in the tubing, and averaging over the measurement paths) were carried out offline using transfer functions with empirically determined time constants (Aubinet et al., 2000). We used here a gap-filled time series, in which measurement gaps were filled with running means. 

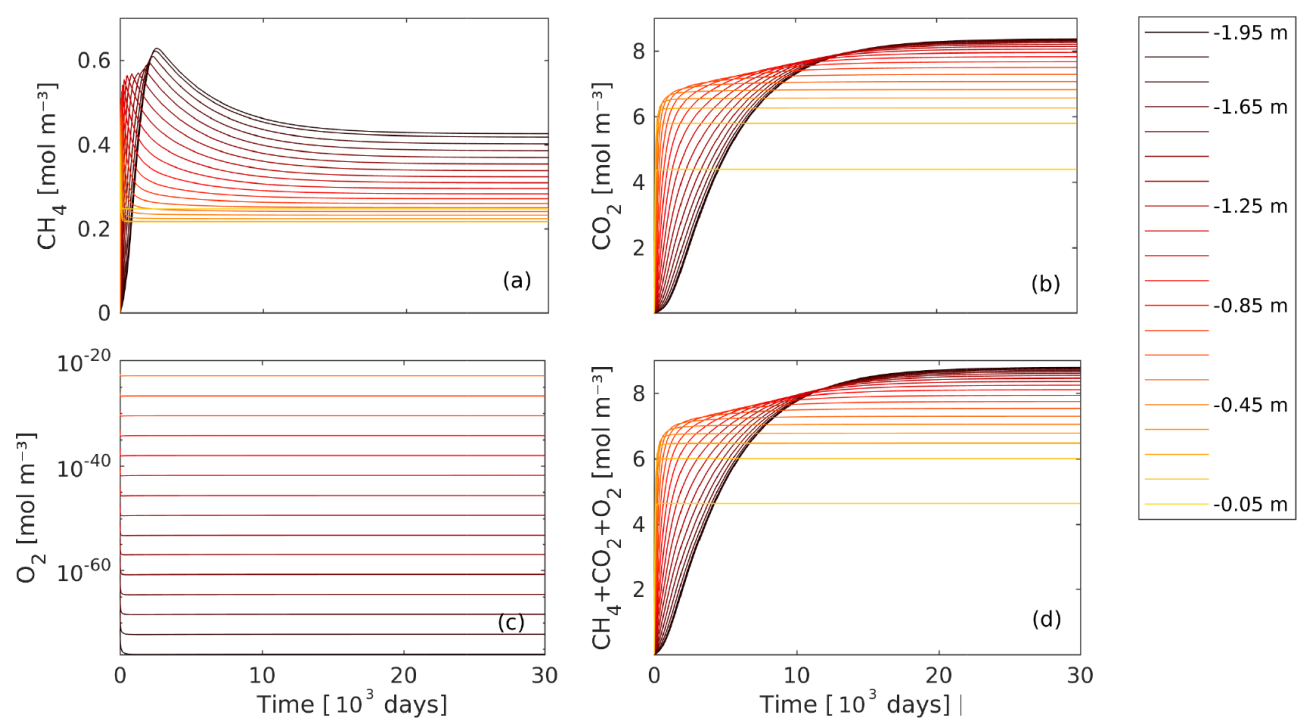

Figure 3. Evolution of the concentration profiles of (a) $\mathrm{CH}_{4}$, (b) $\mathrm{CO}_{2}$, (c) $\mathrm{O}_{2}$, and (d) their sum in a simulation where both WTD and LAI were zero; i.e., there was no plant transport of these compounds. Different colors show the concentrations at different depths in the peat. In the beginning of the simulation, all the concentrations were zero.

\subsubsection{Input data preparation}

We forced the model with daily averages of WTD, peat temperature profile, LAI, and anoxic respiration rate, and compared the results with daily medians of $\mathrm{CH}_{4}$ flux data from the years 2005 to 2011 from Siikaneva and daily averages of $\mathrm{CH}_{4}$ fluxes from the years 2006 to 2010 from Lompolojänkkä. Simulations of LAI and anoxic respiration are described in Appendix B.

In Siikaneva, peat temperature has been monitored at five depths $(-5,-10,-20,-35$, and $-50 \mathrm{~cm})$, and from Lompolojänkkä we had temperature data at -7 and $-30 \mathrm{~cm}$ depths. We created the temperature profiles by interpolating linearly between the measurements. This was done also for the time step test (Sect. 3.3.2). To obtain temperatures below the deepest measurement points, we assumed that the temperature at $-3 \mathrm{~m}$ depth in Siikaneva is constant at $+7^{\circ} \mathrm{C}$, which was the mean temperature of all the years at $-50 \mathrm{~cm}$ depth (according to the measurements), and at Lompolojänkkä the temperature at $-2 \mathrm{~m}$ depth is constant $+4^{\circ} \mathrm{C}$, the mean temperature of all the years at $-30 \mathrm{~cm}$. Gaps in the measurement data were filled by linear interpolation. At Siikaneva, soil temperature data at levels -10 and $-40 \mathrm{~cm}$ were missing over a longer period so this gap was filled by linear interpolation between the adjacent measurement depths. The main component of the input anoxic respiration for Siikaneva was derived from simulated net primary production (NPP). The NPP model was driven with the WTD, photosynthetically active radiation (PAR), and air temperature $\left(T_{\text {air }}\right)$. Long gaps in PAR and $T_{\text {air }}$ data were filled by using corresponding data from a nearby measurement station, SMEAR II (Hari and Kulmala, 2005).

\section{Results and discussion}

\subsection{Model sensitivity to input data}

Via the tests, we wanted to verify that the model dynamics are robust, and to find out how sensitive the output $\mathrm{CH}_{4}$ fluxes are to the input data. Table 4 summarizes the sensitivity results. In the following, we discuss the results, focusing on the most important aspects and primarily on $\mathrm{CH}_{4}$. It is worth noting that these are results from mechanistic sensitivity tests of HIMMELI, not predictions about responses of $\mathrm{CH}_{4}$ emissions to environmental factors in peatland ecosystems but about how HIMMELI will behave when it is used. For example, the total input anoxic respiration rate here was independent of WTD. WTD only governed the number of peat layers into which this input was distributed, and thus the total anoxic respiration rate did not decrease with dropping WTD. Moreover, although soil respiration generally is known to depend on temperature, in these tests there was no dependency between temperature and anoxic respiration rate, which enabled observing the temperature effect within the processes in HIMMELI.

According to the model, the steady-state dissolved $\mathrm{CH}_{4}$ concentrations increase when moving deeper in the peat column (Fig. 3). This results from the increasing hydrostatic pressure that controls the threshold concentration (pressure) above which gases are released as ebullition. As the solubility of $\mathrm{CO}_{2}$ is higher than that of $\mathrm{CH}_{4}$, the saturated $\mathrm{CO}_{2}$ concentrations were higher than $\mathrm{CH}_{4}$ concentrations. In the example shown here, ebullition was driven by $\mathrm{CO}_{2}$. This can be seen in the concentration plots: $\mathrm{CH}_{4}$ concentrations did not reach saturation but stabilized at a value where the sum of the par- 
Table 4. Results of the sensitivity testing. The rightmost column tells how much the $\mathrm{CH}_{4}$ emissions changed when the input changed. The \pm signs in front of "input change" and "change in $\mathrm{CH}_{4}$ emission" show the directions of change in input and the corresponding response in $\mathrm{CH}_{4}$ emissions. This is expressed as percentage of PMP (see Sect. 3.1.3) for the first six tests and as percentage of change in input anoxic respiration for the tests on changing input respiration. In most cases, the response was not constant over the input range, and therefore the result is also expressed as a range.

\begin{tabular}{llll}
\hline Test & Changing input variable & Input change & $\begin{array}{l}\text { Change in } \mathrm{CH}_{4} \text { emission, } \\
\% \text { of potential production/ } \\
\% \text { of change in respiration }\end{array}$ \\
\hline T_W0_L0_R1 & temperature & $+1^{\circ}$ & $+0.01 \ldots 0.02 \%$ \\
T_W0_L1_R1 & temperature & $+1^{\circ}$ & $+0.3 \%$ \\
\hline L_W0_T10_R1 & LAI & $+0.1 \mathrm{~m}^{2}$ & $-13 \ldots-0.3 \%$ \\
L_W03_T10_R1 & LAI & $+0.1 \mathrm{~m}^{2}$ & $-1.8 \ldots-1.4 \%$ \\
\hline W_L0_T10_R1 & WTD & $-0.05 \mathrm{~m}$ & $-1.4 \ldots-0.2 \%$ \\
W_L1_T10_R1 & WTD & $-0.05 \mathrm{~m}$ & $-0.02 \ldots+12 \%$ \\
\hline R_W0_L0_T10 & respiration & + & $+98 \ldots 100 \%$ \\
R_W0_L1_T10 & respiration & + & $+7 \ldots 71 \%$ \\
\hline R_W03_L0_T10 & respiration & + & $+95 \ldots 97 \%$ \\
R_W03_L1_T10 & respiration & + & $+20 \ldots 96 \%$ \\
\hline
\end{tabular}

tial pressures of $\mathrm{N}_{2}, \mathrm{CO}_{2}$, and $\mathrm{CH}_{4}$ was in balance with the combined atmospheric and hydrostatic pressures. LAI was 0 and thus the only transport route of $\mathrm{O}_{2}$ into the soil was diffusion in water-filled peat pores; therefore, $\mathrm{O}_{2}$ concentrations remained very low.

Contribution of different transport routes in the total $\mathrm{CH}_{4}$ flux varied according to model input. Naturally, when LAI was 0 , no $\mathrm{CH}_{4}$ was emitted via plants. Furthermore, because ebullition occurring when the WTD is below the peat surface is transferred to the lowest air-filled peat layer and the gases are then transported by diffusion in dry peat or plant roots (see Sect. 3.1.7), the direct ebullition to the atmosphere occurred only when WTD was at or above the peat surface. Increasing LAI increased the relative contribution of plant transport in the total $\mathrm{CH}_{4}$ emission in tests L_W0_T10_R1 and L_W03_T10_R1 (Fig. 4a; Table 2). Generally, the proportion of plant transport in the total $\mathrm{CH}_{4}$ emissions correlated negatively with the total emission rate, which can be seen in particular in test R_W0_L1_T10 where LAI was constantly 1 and input respiration varied (Fig. 4b). The underlying mechanism here was that high input respiration, i.e., high $\mathrm{CH}_{4}$ and $\mathrm{CO}_{2}$ production, enhanced ebullition (or ebullition followed by transport via diffusion in soil layers above the WTD in the cases with WTD $<0$ ) - as could be expected.

Anoxic respiration rate and the corresponding potential methane production rate (PMP) (tests starting with $\mathrm{R}_{-}$) governed the outputted $\mathrm{CH}_{4}$ emissions. The total emissions depended strongly on the PMP and were only modestly modified by LAI and WTD. The dependency between PMP and $\mathrm{CH}_{4}$ emission was linear, with $R^{2}$ of 1.0 in the cases where LAI was 0 and greater than 0.99 in the cases with LAI of $1 \mathrm{~m}^{2} \mathrm{~m}^{-2}$ (Fig. 5). The percentage of PMP released as $\mathrm{CH}_{4}$

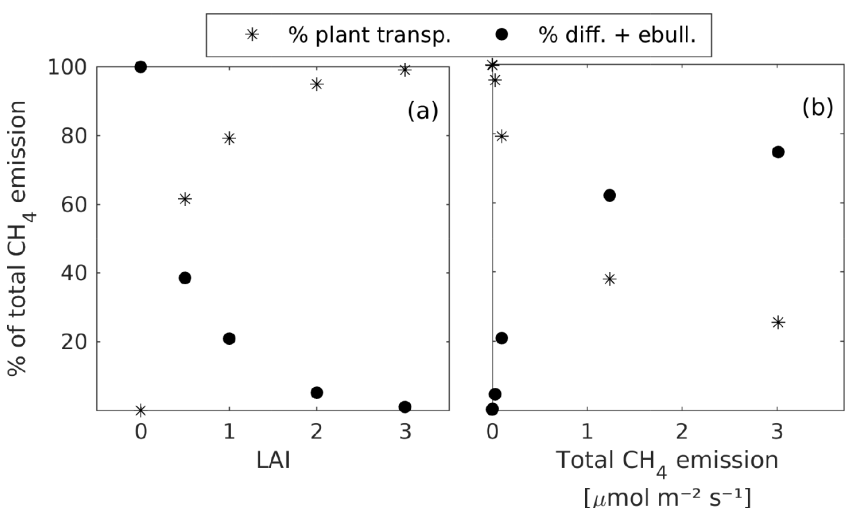

Figure 4. Contribution of different transport routes to the total $\mathrm{CH}_{4}$ emission (a) as a function of LAI in test L_W0_T10_R1 and (b) as a function of total $\mathrm{CH}_{4}$ emission in test R_W0_L1_T10.

emission varied between $5 \%$ and (almost) $100 \%$, the smallest percentages occurring with the lowest anoxic respiration rates. Generally, the lowest values were obtained from test R_W0_L1_T10 because this combination allowed the highest inhibiting effect by $\mathrm{O}_{2}$ (the underlying mechanism is discussed below). The highest emissions occurred when both WTD and LAI were zero in test R_W0_L0_T10. The strong dependency between anoxic respiration and $\mathrm{CH}_{4}$ emission was also demonstrated in the transition test (Fig. 6). The increase/decrease in input respiration affected directly the output $\mathrm{CH}_{4}$ emission rate.

In the tests in which the input respiration was constant and we analyzed the sensitivity of $\mathrm{CH}_{4}$ fluxes to LAI, WTD, and temperature, the final total steady-state $\mathrm{CH}_{4}$ emission 


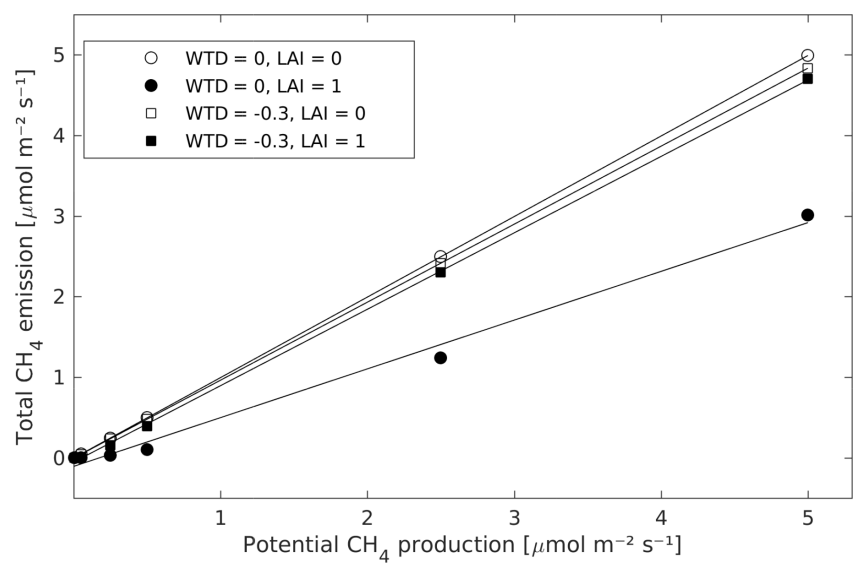

Figure 5. Dependence of the total output $\mathrm{CH}_{4}$ emission on the potential $\mathrm{CH}_{4}$ production rate in tests on the model sensitivity to input anoxic respiration, i.e., tests that were named starting with $R_{-}$.

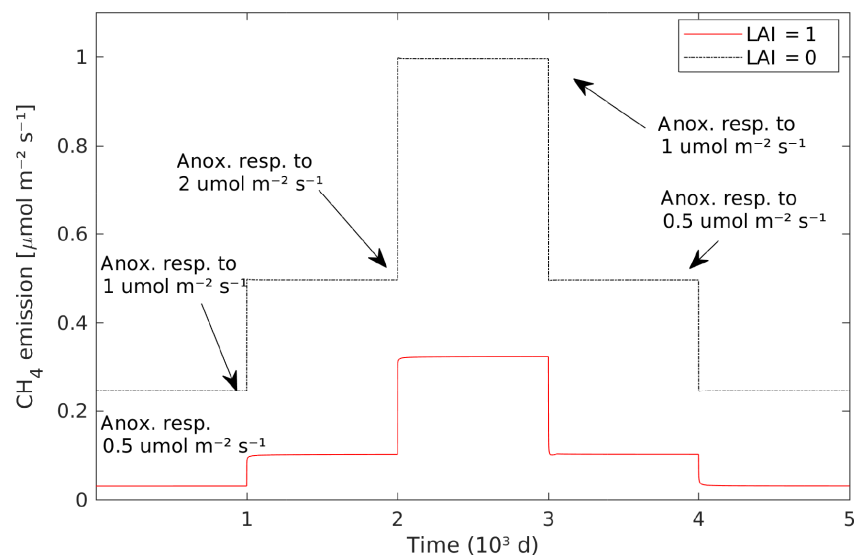

Figure 6. Output $\mathrm{CH}_{4}$ emission responded clearly to changes in the input anoxic respiration rate in the transition tests Rtr_W0_L1 (solid line) and Rtr_W0_L0 (dashed line) (see Table 3). Black arrows indicate when the input changed.

rates varied from $8 \%$ to almost $100 \%$ of PMP. Out of all the test results combined (Fig. 7), the most important governing factor seemed to be LAI; the high emissions required LAI to be zero because that minimized the $\mathrm{O}_{2}$ transport into the soil. Secondarily, WTD controlled the fluxes. The highest emissions occurred when, in addition to zero LAI, WTD was zero or above the peat surface. The effect of temperature was the least important of the input factors, unlike probably in models that describe the total carbon cycle where the rate of anoxic respiration depends on temperature. In our tests, temperature affected only those processes that HIMMELI itself simulates (transport, oxidation, aerobic respiration). However, also with HIMMELI, the largest $\mathrm{CH}_{4}$ emissions occurred in the tests with high temperatures.

Although temperature did not have a significant effect in steady state, temperature change in the temperature transition tests had a clear effect on the $\mathrm{CH}_{4}$ emissions (Fig. 8).

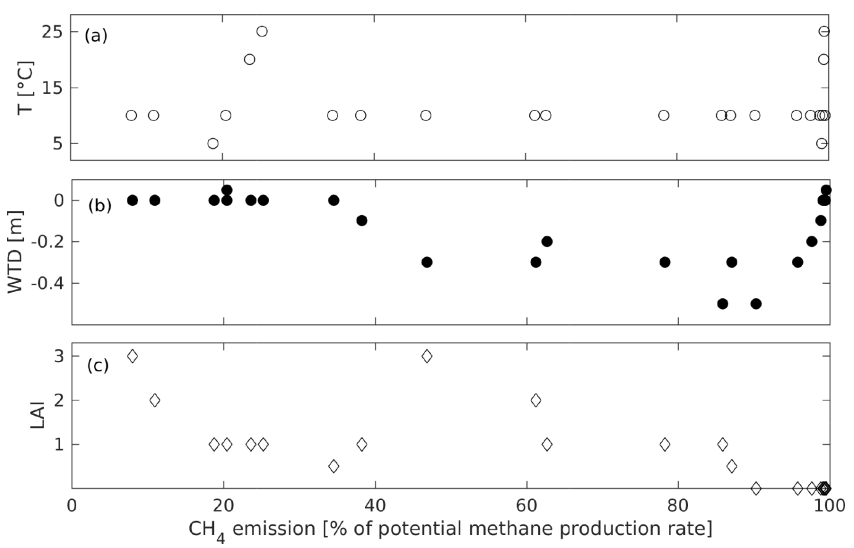

Figure 7. Relationship between the relative $\mathrm{CH}_{4}$ emission rate (expressed as percentage of PMP) and different combinations of input (a) temperature, (b) WTD, and (c) LAI in the steady-state sensitivity tests with constant anoxic respiration (test names ending with -R1).

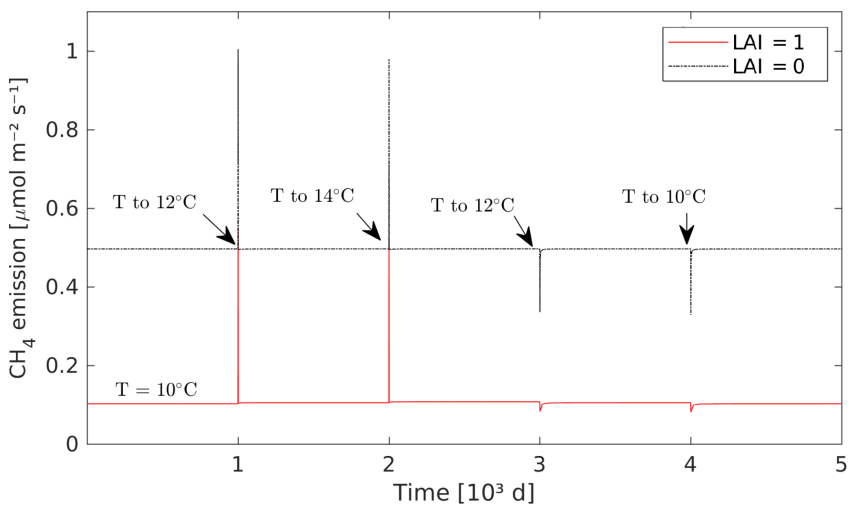

Figure 8. Response of $\mathrm{CH}_{4}$ emission to changes in peat temperature in the transition tests Ttr_W0_L1 (red line) and Ttr_W0_L0 (black dashed line) (see Table 3). Black arrows indicate when the input changed.

A $2^{\circ}$ abrupt temperature rise throughout the peat column caused the emissions to peak momentarily, before settling to a level only moderately higher than before. The $2^{\circ}$ temperature drops were, correspondingly, followed by a few days of clear depression in the emissions, until they gradually recovered back to the normal level. This resulted from temperature transitions changing the gas solubilities and thus the volume of gases available for ebullition.

One interesting result was that the $\mathrm{CH}_{4}$ emissions decreased with decreasing WTD in test W_L0_T10_R1 in which plant transport played no role (Fig. 9a). This was controlled by the oxidation rate that depends on the thickness of the dry oxic peat layer. However, when plant transport was included in W_L1_T10_R1, the highest emissions occurred with the deepest WTD (Fig. 9b) because then the root mass available for transporting $\mathrm{O}_{2}$ into the $\mathrm{CH}_{4}$-producing peat layers was at its lowest. The same trends were obvious in the 


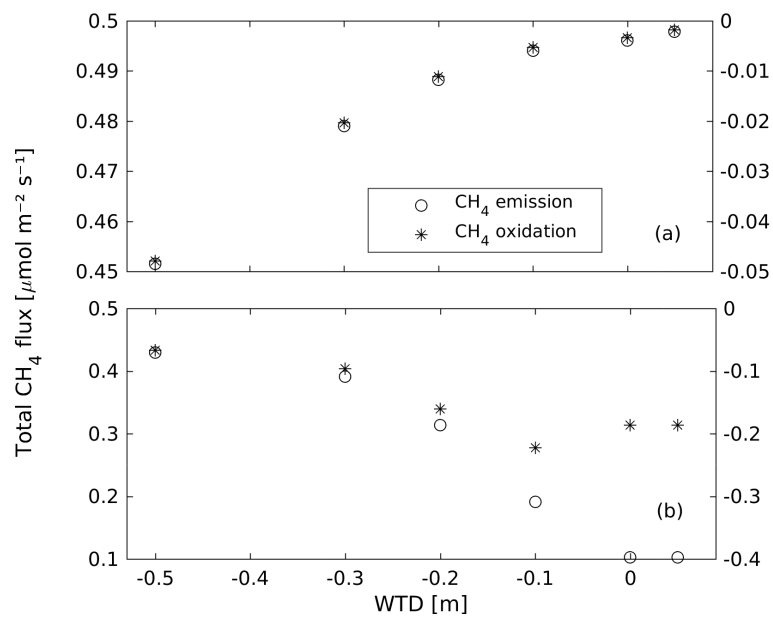

Figure 9. Dependence of the total $\mathrm{CH}_{4}$ flux and $\mathrm{CH}_{4}$ oxidation rate on WTD in (a) test W_L0_T10_R1 and (b) test W_L1_T10_R1. $\mathrm{CH}_{4}$ oxidation is a negative flux since it is a loss of $\mathrm{CH}_{4}$.

transition tests with changing WTD (Wtr_L1 and Wtr_L0; Fig. 10); dropping WTD caused increasing emissions when LAI was 1 but decreased them when LAI was 0 .

The main conclusion that can be deduced from the results reviewed above is that $\mathrm{O}_{2}$ concentration was an important player in the simulations. It affected both the inhibition of $\mathrm{CH}_{4}$ production and oxidation of $\mathrm{CH}_{4}$ to $\mathrm{CO}_{2}$ (Eqs. 6 and 8). In the tests with constant input respiration (tests ending with _R1), the actualized $\mathrm{CH}_{4}$ production rate varied from $38 \%$ to (very close to) $100 \%$ of the PMP, and the highest inhibition of $\mathrm{CH}_{4}$ production (i.e., lowest $\mathrm{CH}_{4}$ production) occurred with high LAI that allowed high $\mathrm{O}_{2}$ plant transport into the soil. The same pattern was obvious in the tests on varying input respiration ( $\left.\mathrm{R}_{-}\right)$. When LAI was 0 , the $\mathrm{CH}_{4}$ production was more or less equal to the PMP. When LAI was 1 and WTD was $-0.3 \mathrm{~m}$, the production was 95 to $98 \%$ of the PMP. When LAI was 1 and WTD was 0 , i.e., all the roots were inundated, the production was at its lowest and varied between 53 and $71 \%$ of PMP. This indicates that the more $\mathrm{O}_{2}$ was transported to those soil layers that produced $\mathrm{CH}_{4}$, the less $\mathrm{CH}_{4}$ was produced and consequently emitted. Whether the same production was distributed either in the entire $2 \mathrm{~m}$ peat column or only, e.g., in the bottom $1.7 \mathrm{~m}$ was significant since in the latter case, there was less $\mathrm{O}_{2}$ transported as a whole to the $\mathrm{CH}_{4}$-producing soil layers, because the greatest root mass is allocated into the topmost peat layers.

The impact of temperature on the output fluxes in the steady-state tests was also transmitted via $\mathrm{O}_{2}$ availability. A $1^{\circ}$ increase in peat temperature increased the total methane emissions on average by $0.09 \mathrm{nmol} \mathrm{m}^{-2} \mathrm{~s}^{-1}$ (0.01 to $\left.0.02 \%\right)$ without gas-transporting vegetation (T_W0_L0_R1) and $1.6 \mathrm{nmol} \mathrm{m}^{-2} \mathrm{~s}^{-1}(0.3 \%)$ with vegetation (T_W0_L1_R1). The dependencies were linear, with $R^{2}$ of 0.98 and 1.0 , re-

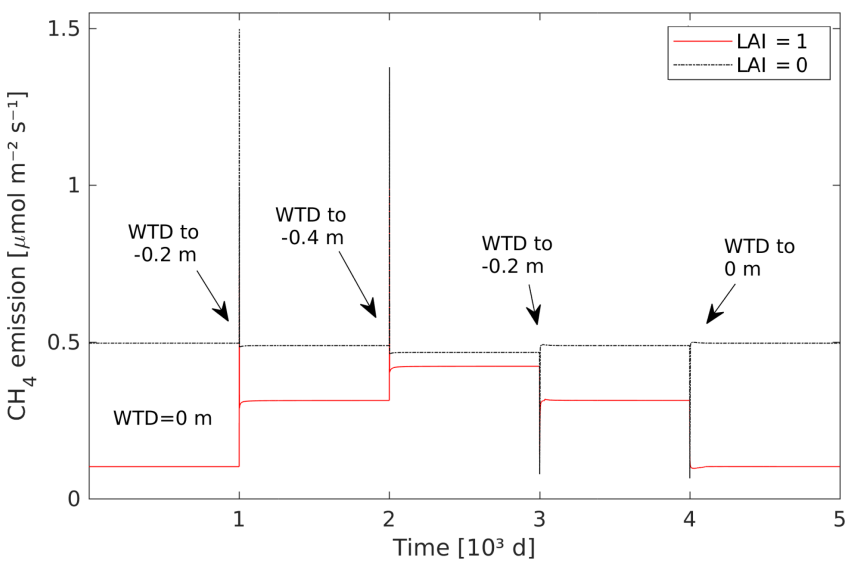

Figure 10. Effect of abrupt changes in WTD on the total output $\mathrm{CH}_{4}$ emissions in transition tests Wtr_L0 (dashed line) and Wtr_L1 (solid line). Black arrows indicate the change in WTD. This figure also shows how changes in the WTD cause a short peak in the flux, because of how the $\mathrm{CH}_{4}$ (and $\mathrm{CO}_{2}$ and $\mathrm{O}_{2}$ ) in layers receiving or losing water is handled in the model (see Sect. 3.1.2).

spectively. The main reason for this was that in cold temperatures, the solubility of gases and thus the concentrations of dissolved $\mathrm{O}_{2}$ in water were higher. Therefore, the $\mathrm{CH}_{4}$ oxidation and inhibition of $\mathrm{CH}_{4}$ production were highest in low temperatures although the rates of these reactions were at their lowest (Eq. 9).

The tests thus revealed that $\mathrm{O}_{2}$ transport and other $\mathrm{O}_{2}$ related processes also deserve attention in $\mathrm{CH}_{4}$ modeling, when $\mathrm{O}_{2}$ concentrations are simulated. It is known that the strictly anoxic methanogens are inhibited by $\mathrm{O}_{2}$ (CelisGarcía et al., 2004) and so it is important to have a proper description of the inhibition process in the $\mathrm{CH}_{4}$ models. $\mathrm{O}_{2}$ transport of aerenchymatous plants has been measured in laboratory conditions (Moog and Brüggemann, 1998) and in the field (Mainiero and Kazda, 2004) but there seem to be no studies in which the simulated plant transport of $\mathrm{O}_{2}$, its dependency on model inputs like LAI, or even the dissolved $\mathrm{O}_{2}$ concentrations have been compared with measurements. Measuring $\mathrm{O}_{2}$ fluxes with traditional chambers is challenging because detecting small changes in the high atmospheric $\mathrm{O}_{2}$ concentration (21\%) is difficult (Brix and Sorrell, 2013). Consequently, observational $\mathrm{O}_{2}$ data for validating the $\mathrm{O}_{2}$ side of $\mathrm{CH}_{4}$ models are largely lacking.

As mentioned above, effects of the input factors on $\mathrm{CH}_{4}$ emissions may be different when taking the whole peatland carbon cycle into consideration. For example, in test L_W0_T10_R1, high LAI meant high $\mathrm{CH}_{4}$ plant transport capacity that intuitively could mean high $\mathrm{CH}_{4}$ emissions. However, here the impact of increased plant transport of $\mathrm{O}_{2}$ into the soil was so strong that, as a result, the total $\mathrm{CH}_{4}$ emissions were lower with high LAI (Fig. 11). Root exudates of gas-transporting plants have been suggested to be a significant source of $\mathrm{CH}_{4}$ substrates (Whiting and Chan- 


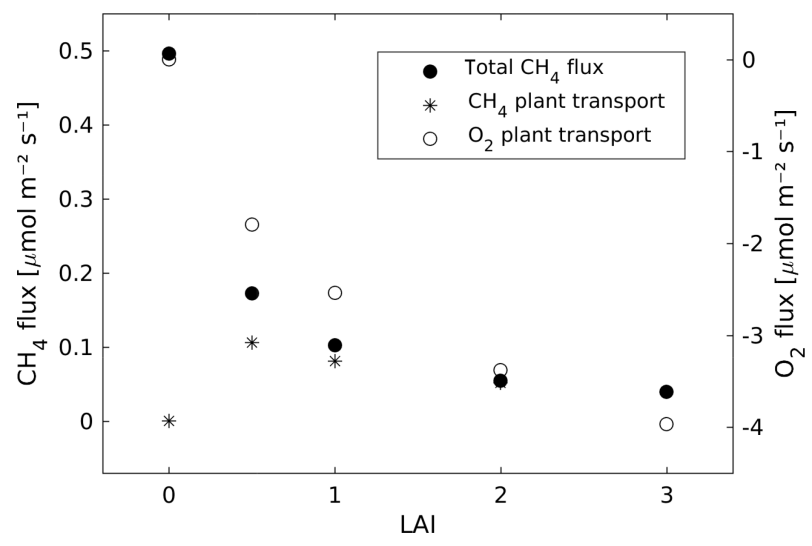

Figure 11. Dependence of total and plant-transported fluxes of $\mathrm{CH}_{4}$ and plant transport of $\mathrm{O}_{2}$ on LAI in test L_W0_T10_R1.

ton, 1993), and unlike in these sensitivity tests, a greater LAI would probably also mean higher $\mathrm{CH}_{4}$ substrate input in nature. We tested this by setting the input respiration to depend linearly on LAI, assuming zero respiration when LAI was 0 . In this case, the total $\mathrm{CH}_{4}$ emissions depended on the input respiration and increased with increasing LAI, as could be expected to happen when HIMMELI is connected to a full peatland carbon model.

Direct comparison of our results and sensitivity studies done on other peatland $\mathrm{CH}_{4}$ emission models is not worthwhile because the other studies have analyzed the response of the total peatland carbon model. Some observations can, however, be made. In several studies, the parameters affecting the $\mathrm{CH}_{4}$ production rate have been found important (Wania et al., 2010; Berrittella and van Huissteden, 2011), which corresponds to our result that the input anoxic respiration rate affects the output significantly. Wania et al. (2010) tested the effect of tiller porosity on the $\mathrm{CH}_{4}$ emissions and found that at four out of five of their sites, greater porosity increased the total $\mathrm{CH}_{4}$ flux because of enhanced plant transport of $\mathrm{CH}_{4}$, despite the fact that also $\mathrm{O}_{2}$ transport increased. However, in their model, $\mathrm{O}_{2}$ did not affect the $\mathrm{CH}_{4}$ production rate. In our tests, PMP was not dependent on temperature, and hence the total effect of temperature was mediated via gas solubilities and rates of oxidation and inhibition. In a complete peatland model, also $\mathrm{CH}_{4}$ production will depend on temperature, and as the temperature sensitivity of $\mathrm{CH}_{4}$ production is known to be high (Segers, 1998), that would probably outweigh the other temperature dependencies (Riley et al., 2011). For the development of process-based $\mathrm{CH}_{4}$ models, it is thus useful to analyze the effects of temperature also independently of carbon input. Tang et al. (2010) studied the response of their models to changes in WTD and found that increasing the WTD retarded the $\mathrm{CH}_{4}$ emissions probably because the diffusivity in water is lower than in the air. Whether the increasing WTD affected the total $\mathrm{CH}_{4}$ production is not discussed in their study.

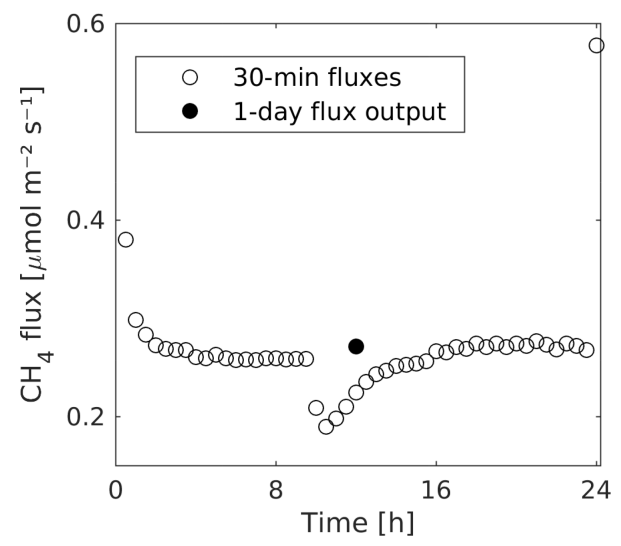

Figure 12. Daily $\mathrm{CH}_{4}$ flux in the test comparing $30 \mathrm{~min}$ and daily time steps.

\subsection{Effect of diurnal temperature variation and time step length}

Comparing the outputs of the model run using a 30 min time step with the outputs from the run with a daily time step showed that eliminating the diurnal temperature variation does not have any significant effect on the model output. When using the shorter time step, diurnal variation in the flux was evident and, for instance, a small (around 0.05 to $0.1^{\circ}$ ) temperature increase throughout the peat column below $0.5 \mathrm{~m}$ depth during the last hour caused a clear peak in the emissions (Fig. 12). However, within this setup, the daily average $\mathrm{CH}_{4}$ emission rate of the $30 \mathrm{~min}$ run and the daily output from the 1-day run were equal to two decimal places, $0.27 \mu \mathrm{mol} \mathrm{m}{ }^{-2} \mathrm{~s}^{-1}$. The simulation did not relate the anoxic respiration rate to temperature; however, this result indicates that HIMMELI produces consistent output irrespective of the time step length.

\subsection{Model sensitivity to the description of the peat column}

The sensitivity tests with different soil layerings and peat thicknesses conducted using the input data set from $\mathrm{Si}$ ikaneva site showed that the setup of the peat column does not have any significant effect on the output. The mean total $\mathrm{CH}_{4}$ flux was between 17.5 and $18.5 \mathrm{nmol} \mathrm{m}^{-2} \mathrm{~s}^{-1}$ for all the setups. There were no striking differences in the simulated time series (Fig. 13) and so they all followed the measured $\mathrm{CH}_{4}$ fluxes similarly (Fig. 14a). The same applied to plant transport of $\mathrm{CH}_{4}$; the mean plant-transported flux was approximately $14 \mathrm{nmol} \mathrm{m}^{-2} \mathrm{~s}^{-1}$ in all the cases. Direct ebullition to the atmosphere occurred only a few times during this 7-year simulation and so it was not a significant contribution to the total $\mathrm{CH}_{4}$ emissions (thus not shown). The maximum peak direct ebullition to the atmosphere (daily average) fell between 11 and $12 \mathrm{nmol} \mathrm{m}^{-2} \mathrm{~s}^{-1}$ in all other cases, except with the logarithmic layering it was around $17 \mathrm{nmol} \mathrm{m}^{-2} \mathrm{~s}^{-1}$. 

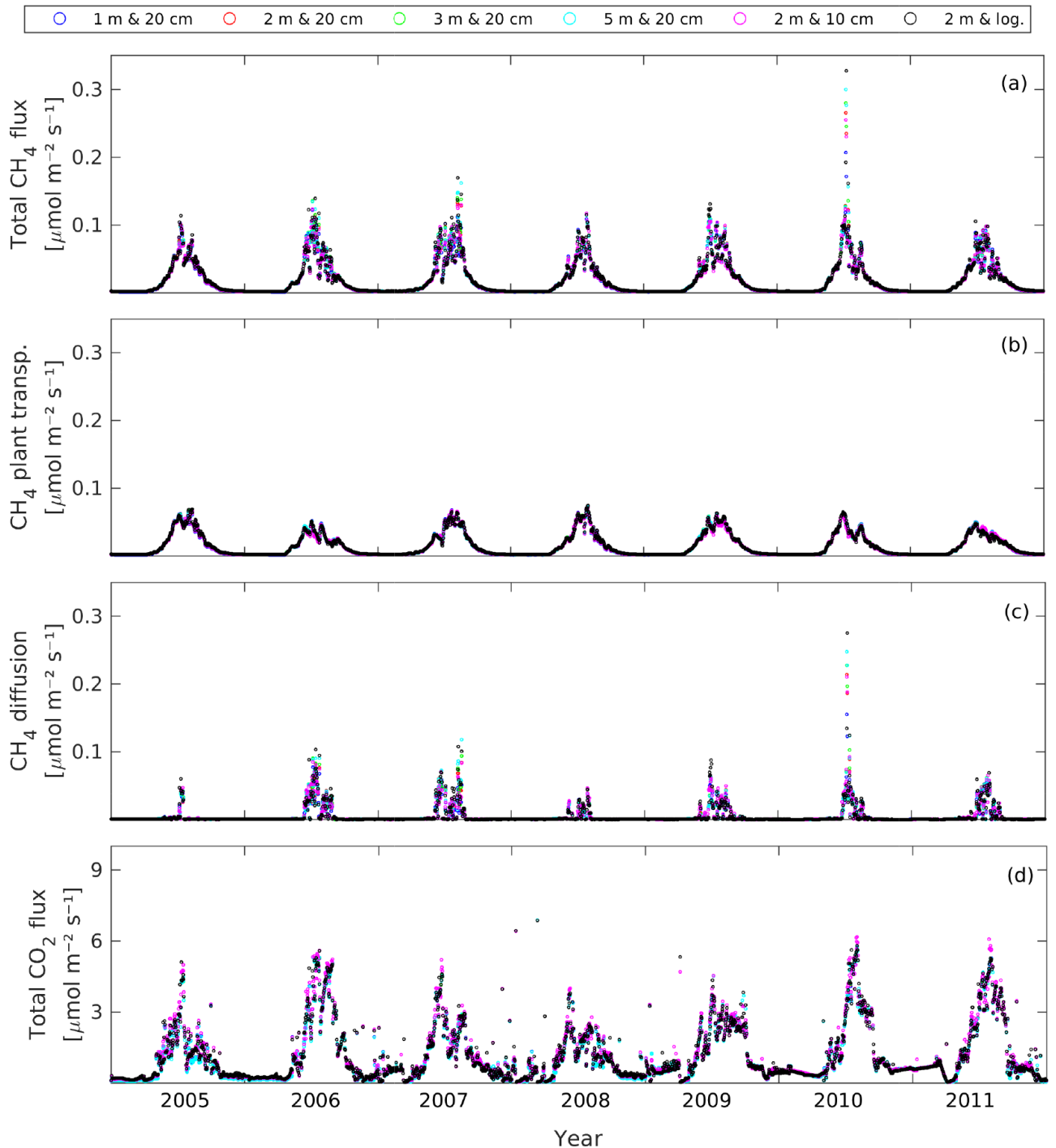

Figure 13. Time series of $\mathrm{CH}_{4}$ and $\mathrm{CO}_{2}$ fluxes simulated for Siikaneva from 2005 to 2011, using different peat depths and layer thicknesses with the same input anoxic respiration rate: (a) total $\mathrm{CH}_{4}$ flux, (b) $\mathrm{CH}_{4}$ plant transport, (c) $\mathrm{CH}_{4}$ diffusion, and (d) total $\mathrm{CO}_{2}$ flux. Direct ebullition to the atmosphere was negligible and thus not shown. $\mathrm{CH}_{4}$ ebullited when WTD below the peat surface was transported to the atmosphere via diffusion in peat or plant roots.

The remains of the total flux, the mean being between 3 and $4 \mathrm{nmol} \mathrm{m}^{-2} \mathrm{~s}^{-1}$ in each case, was transported by diffusion in the peat. This diffusion flux contained ebullited $\mathrm{CH}_{4}$ that originated from the water-filled peat layers when the WTD was below the peat surface, which was mostly the case. Also, the total $\mathrm{CO}_{2}$ flux was similar in all the setups (Fig. 13d). The mean total $\mathrm{CO}_{2}$ flux was 1.1 to $1.2 \mu \mathrm{mol} \mathrm{m}^{-2} \mathrm{~s}^{-1}$ in all the cases.

This sensitivity test indicated that when simulating $\mathrm{CH}_{4}$ fluxes with HIMMELI, it is not worthwhile to describe a deep peat column with dense layering because it does not significantly improve the accuracy of the simulation compared with a faster setup, such as a logarithmic layer structure that is often used in land surface models. The logarithmic layering gave - within the experimental accuracy - a similar result to the $10 \mathrm{~cm}$ layers, when the input data were the same. Principal reasons probably were that the $\mathrm{CH}_{4}$ production was now allocated mainly to the topmost peat layers, following the vertical root distribution (Eq. 4) and that the $\mathrm{CO}_{2}$ flux was driven by aerobic peat respiration in layers above the WTD. The emission peaks of all the different setups coincided in 2010, despite the fact that the peat thicknesses differed. Based on the temperature transition tests, the underlying reason here seemed to be a relatively abrupt temperature rise in peat layers, which did not occur in other years. This, probably together with sinking WTD, triggered ebullition from the water-filled peat layers similarly in all the cases, and the ebullited $\mathrm{CH}_{4}$ is seen as a peak in the diffusion flux. 

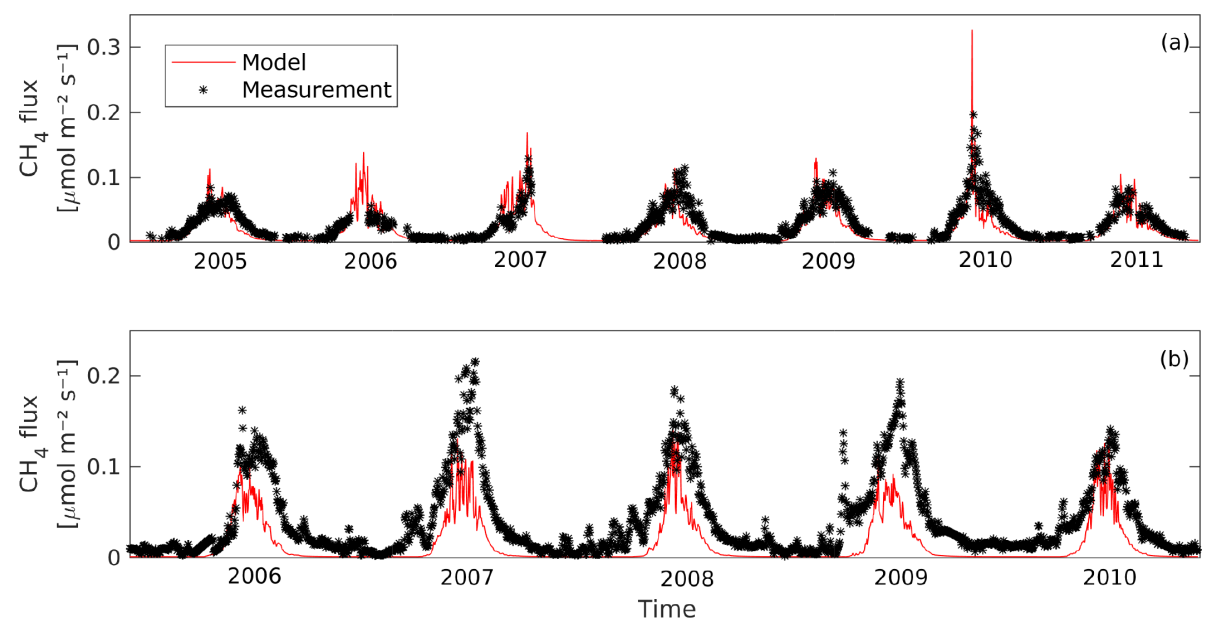

Figure 14. Comparison of simulated and measured $\mathrm{CH}_{4}$ emissions (a) at Siikaneva and (b) at Lompolojänkkä. The simulations used the logarithmic layer structure and $2 \mathrm{~m}$ of peat.

\subsection{Comparison of modeled and measured $\mathrm{CH}_{4}$ fluxes}

The anoxic respiration inputs created for Siikaneva and Lompolojänkkä (Appendix B) had a clear annual pattern and the rates varied between 0.02 and $0.6 \mu \mathrm{mol} \mathrm{m}^{-2} \mathrm{~s}^{-1}$ for Siikaneva and between 0.01 and $1.5 \mu \mathrm{mol} \mathrm{m}^{-2} \mathrm{~s}^{-1}$ for Lompolojänkkä. This magnitude is within literature values. Szafranek-Nakonieczna and Stepniewska (2014) observed anaerobic $\mathrm{CO}_{2}$ production in peat incubations ranging up to around $0.1 \mathrm{~g}\left(\mathrm{CO}_{2}\right) \mathrm{kg}^{-1}$ (dry weight) $\mathrm{d}^{-1}$, which corresponds to around $4 \mu \mathrm{mol} \mathrm{m}{ }^{-2} \mathrm{~s}^{-1}$ assuming peat bulk density of $80 \mathrm{~g} \mathrm{dm}^{-3}$ (Turunen et al., 2002) and $2 \mathrm{~m}$ of peat. A model of peat respiration, parameterized by Riutta et al. (2007) using measurement data from a peatland site similar to $\mathrm{Si}$ ikaneva, gave a respiration rate of $0.5 \mu \mathrm{mol} \mathrm{m} \mathrm{m}^{-2} \mathrm{~s}^{-1}$ at air temperature of $20^{\circ} \mathrm{C}$ and WTD of zero (full inundation).

Figure 14 shows the daily observed $\mathrm{CH}_{4}$ fluxes and the $\mathrm{CH}_{4}$ fluxes simulated using the logarithmic layer structure in a $2 \mathrm{~m}$ deep peat column at Siikaneva and Lompolojänkkä. Magnitude of the modeled emissions is comparable to the observed fluxes although there is some difference, especially at Lompolojänkkä. The measured $\mathrm{CH}_{4}$ emissions were on average 80 and $140 \%$ of the modeled emissions at Siikaneva and Lompolojänkkä, respectively. It is also clear, especially at Lompolojänkkä, that the simulated annual emission pattern deviates from the observations; the modeled emissions tend to increase too late in spring and decrease too early in the autumn. This may be partly due to a biased presentation of changes in LAI but principally the reason was a biased annual pattern of input anoxic respiration. The main component of the anoxic respiration was derived directly from simulated daily NPP and it produced $\mathrm{CH}_{4}$ and $\mathrm{CO}_{2}$ immediately, without any time lag, for example, via pools of decomposing organic compounds that could be important at least in the autumn. In reality, as well as in soil carbon models with which HIMMELI could be combined, there is some lag in the process of carbon fixation turning into root exudates and further to $\mathrm{CH}_{4}$. Most probably both the magnitude and the annual pattern of the emissions can be improved by more realistic simulation of anoxic respiration. However, the model explained the variation in emissions relatively well: the $R^{2}$ between model and measurement was 0.63 at Siikaneva and 0.70 at Lompolojänkkä.

The simulated $\mathrm{CO}_{2}$ emissions were also at realistic levels both at Siikaneva and Lompolojänkkä. According to Aurela et al. (2007), the mean respiration in Siikaneva in July 2005 was 1.1 to $2.3 \mu \mathrm{mol} \mathrm{m}^{-2} \mathrm{~s}^{-1}$ and in our simulation, the mean $\mathrm{CO}_{2}$ emission in July 2005 was 2.4 to $2.8 \mu \mathrm{mol} \mathrm{m} \mathrm{m}^{-2} \mathrm{~s}^{-1}$ (Fig. 15). At Lompolojänkkä, monthly respiration of July 2006 to 2008 was around $2.5 \mu \mathrm{mol} \mathrm{m}^{-2} \mathrm{~s}^{-1}$ (Aurela et al., 2009), while the model simulated a $\mathrm{CO}_{2}$ flux of $3.5 \mu \mathrm{mol} \mathrm{m}{ }^{-2} \mathrm{~s}^{-1}$ (data not shown). The model overestimated slightly the emissions, especially given that it does not include $\mathrm{CO}_{2}$ from autotrophic respiration unlike the observed fluxes, but the result is still reasonable.

Summer 2010 at Siikaneva was interesting since both model and measurements showed the highest emission peaks then. The maximum emissions do not coincide exactly on the same days, but they are temporally close. In HIMMELI, the main reason was an exceptionally abrupt temperature rise in the peat water, followed by decreasing gas solubilities and increased ebullition - as was observed in the temperature transition tests. Summer 2010 was unusually hot in Finland and so the heat can very well be the cause of the observed high emissions also in nature. We do not know whether the effect really can be transmitted via gas solubilities instead of, for instance, increased respiration. Grant and Roulet (2002) compared simulated and measured $\mathrm{CH}_{4}$ emissions at a beaver pond. Their model captured some bubbling events, driven by warming soil that affected both fermentation and methano- 

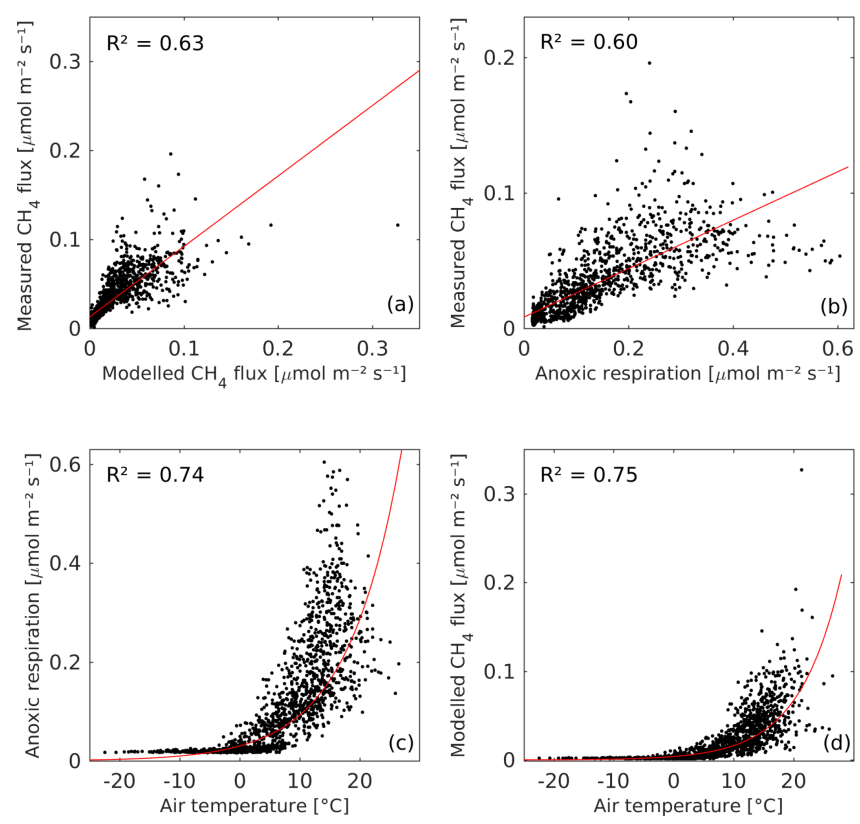

Figure 15. Correlations between (a) modeled and measured $\mathrm{CH}_{4}$ flux, (b) input anoxic respiration and measured $\mathrm{CH}_{4}$ flux, (c) observed air temperature and input anoxic respiration, and (d) observed air temperature and modeled $\mathrm{CH}_{4}$ flux. The data are from the Siikaneva test (Fig. 14a).

genesis rates and gas solubilities. In our case, the simulated input anoxic respiration did not increase noticeably during this high-emission period, but our simulation may underestimate the effect of temperature. Moreover, although the soil temperature profile used to run the model was derived from measurements, it was an approximation, as it was created by linear interpolation between measurement points. The temperature change of the lower peat layers may be exaggerated compared to reality. However, the modeled $\mathrm{CH}_{4}$ emission peaks nicely matched with observations.

Taking a closer look at Siikaneva only, the model was a slightly better predictor for the measured $\mathrm{CH}_{4}$ emissions than the anoxic respiration as such (Fig. 15), with $R^{2}$ values of 0.63 vs. 0.60 . Hence, considering the anoxic respiration simulation combined with HIMMELI as one unified $\mathrm{CH}_{4}$ model, HIMMELI slightly improved the fit compared to the anoxic respiration part alone. In the data set shown in the correlation plots (Fig. 15), which was limited to those days from which the measured $\mathrm{CH}_{4}$ fluxes were available, the $R^{2}$ between input anoxic respiration and modeled $\mathrm{CH}_{4}$ emissions was 0.65 . In the complete simulated time series, this $R^{2}$ was 0.69 and when correlating the $\mathrm{CH}_{4}$ emissions with anoxic respiration of the previous day, $R^{2}$ still slightly increased up to 0.71 . In the complete time series, the simulated $\mathrm{CH}_{4}$ emissions were on average $15 \%$ of the input anoxic respiration or $30 \%$ of PMP. These results support the findings from the sensitivity tests (Sect. 4.1) that anoxic respiration rate and the corresponding PMP do govern the output $\mathrm{CH}_{4}$ emissions but indicate also that oxidation and inhibition played a role in the site simulation of Siikaneva. The temperature responses of anoxic respiration and modeled $\mathrm{CH}_{4}$ emissions were very similar (Fig. 15).

Anoxic respiration alone thus seems a good basis to estimate $\mathrm{CH}_{4}$ emissions, but a complete model of $\mathrm{CH}_{4}$ processes is necessary, also in situations when the focus is not on studying concentration profiles or the processes in detail. Simple parameterizations have been tested against processbased $\mathrm{CH}_{4}$ models. For example, van Huissteden et al. (2009) compared the peatland model PEATLAND-VU, that utilizes the Walter-Heimann $\mathrm{CH}_{4}$ scheme, with an emission factor that was based on averages of measurement data on six arctic and temperate wetlands. They found that the model produced a significantly better estimate only on $50 \%$ of the sites; on the others, the simple emission factor did better or almost equally as well. They concluded, however, that process models are needed for large-scale modeling. Berrittella and van Huissteden (2009) compared PEATLAND-VU to a fixed fraction of NPP as the estimate of $\mathrm{CH}_{4}$ emissions when simulating northern wetlands in glacial climates. In this case, they naturally did not have real-time observational flux data to compare their results with, but they concluded that the two approaches gave different results; for instance, the simplistic NPP model produced smaller differences between glacial climates than PEATLAND-VU. A $\mathrm{CH}_{4}$ model like HIMMELI is a significant addition to peatland carbon models, in order to be able to take into account more factors affecting $\mathrm{CH}_{4}$ emissions.

\section{Conclusions}

The new model for simulating $\mathrm{CH}_{4}$ build-up and emissions in peatlands, HIMMELI, is a robust tool to be used as the $\mathrm{CH}_{4}$ emission model in different peatland carbon models. It runs well with different peat column setups and within a wide range of inputs. The simulated $\mathrm{CH}_{4}$ emissions are not sensitive to the description of the peat column in the event it does not affect the input variables. HIMMELI was able to simulate realistic $\mathrm{CH}_{4}$ fluxes for the Finnish peatland sites Siikaneva and Lompolojänkkä when run with measured and simulated input from the sites.

Sensitivity tests conducted on HIMMELI revealed mechanisms controlling the simulated $\mathrm{CH}_{4}$ emissions that may remain hidden when testing the sensitivity of a full peatland carbon cycle model. Simulated $\mathrm{CH}_{4}$ fluxes largely depended on the input anoxic respiration rate and the corresponding $\mathrm{CH}_{4}$ production rate. This shows that in addition to correct descriptions of $\mathrm{CH}_{4}$ and $\mathrm{O}_{2}$ transport and oxidation processes, it is essential that the underlying $\mathrm{CH}_{4}$ substrate production rates are realistic, in order to produce realistic $\mathrm{CH}_{4}$ emission estimates for different purposes. Other input variables, in particular LAI and WTD, also had an impact on the $\mathrm{CH}_{4}$ emissions in the steady-state tests. With constant in- 
put anoxic respiration (which means constant potential $\mathrm{CH}_{4}$ production rate), the total $\mathrm{CH}_{4}$ emission varied from $5 \%$ to almost $100 \%$ of the potential $\mathrm{CH}_{4}$ production, depending on the combination of LAI and WTD. The results indicated that the main factor governing this was the availability of $\mathrm{O}_{2}$ in the peat since its concentration affected the inhibition of $\mathrm{CH}_{4}$ production as well as rates of $\mathrm{CH}_{4}$ oxidation to $\mathrm{CO}_{2}$.
Code and data availability. The Fortran codes of the HIMMELI model are available as a Supplement to this article. The data used in these analyses are available upon request. 


\section{Appendix A}

The solubilities of gases are computed following Sander (2015). The temperature $(T)$ dependence of Henry's law constants for the three simulated compounds $\mathrm{CH}_{4}, \mathrm{CO}_{2}$, and $\mathrm{O}_{2}\left(H_{X} ; \mathrm{M} \mathrm{atm}^{-1}\right)$ thus is (Eqs. A1-A3)

$$
\begin{aligned}
& H_{\mathrm{CH}_{4}}(T)=1.3 \times 10^{-3} \exp \left[1700\left(\frac{1}{T}-\frac{1}{T^{\theta}}\right)\right] \\
& H_{\mathrm{O}_{2}}(T)=1.3 \times 10^{-3} \exp \left[1500\left(\frac{1}{T}-\frac{1}{T^{\theta}}\right)\right] \\
& H_{\mathrm{CO}_{2}}(T)=3.4 \times 10^{-2} \exp \left[2400\left(\frac{1}{T}-\frac{1}{T^{\theta}}\right)\right],
\end{aligned}
$$

where $T^{\theta}$ is the reference temperature, $298 \mathrm{~K}$. Temperaturedependent diffusivities of the three compounds in water $\left(D_{X, \mathrm{w}} ; \mathrm{m}^{2} \mathrm{~s}^{-1}\right)$ and in air $\left(D_{X, \mathrm{a}} ; \mathrm{m}^{2} \mathrm{~s}^{-1}\right)$ are calculated following Tang et al. (2010) (Eqs. A4-A9). The reference temperature $T^{\theta b}$ used in Eqs. (A7)-(A9) is $273.15 \mathrm{~K}$.

$$
\begin{aligned}
& D_{\mathrm{CH}_{4}, \mathrm{w}}(T)=1.5 \times 10^{-9} \frac{T}{T^{\theta}} \\
& D_{\mathrm{O}_{2}, \mathrm{w}}(T)=2.4 \times 10^{-9} \frac{T}{T^{\theta}} \\
& D_{\mathrm{CO}_{2}, \mathrm{w}}(T)=1.81 \times 10^{-6} \exp \left(\frac{-2032.6}{T}\right) \\
& D_{\mathrm{CH}_{4}, \mathrm{a}}(T)=1.9 \times 10^{-5}\left(\frac{T}{T^{\theta b}}\right)^{1.82} \\
& D_{\mathrm{O}_{2}, \mathrm{a}}(T)=1.8 \times 10^{-5}\left(\frac{T}{T^{\theta b}}\right)^{1.82} \\
& D_{\mathrm{CO}_{2}, \mathrm{a}}(T)=1.47 \times 10^{-5}\left(\frac{T}{T^{\theta b}}\right)^{1.792} .
\end{aligned}
$$

\section{Appendix B}

LAI is not continuously monitored at the peatland sites Siikaneva and Lompolojänkkä; therefore, we utilized the method introduced by Wilson et al. (2007) to obtain LAI input data for the model runs. We simulated the LAI with a lognormal function (Wilson et al., 2007) (Eq. B1):

$\operatorname{LAI}(j)=\operatorname{LAI}_{\max } \times e^{\left(-0.5\left(\frac{\ln \left(\frac{j}{j \max }\right)}{s}\right)^{2}\right)}$,

where $\mathrm{LAI}_{\max }$ is the peak LAI of the growing season, $j$ is the Julian date, $j_{\max }$ is the Julian date when the LAI peaks, and $s$ denotes the shape of the curve. Values for the parameters $j_{\max }$ and $s$ (Table B1) for Siikaneva were derived from Wilson et al. (2007) by averaging the values reported for the species abundant at Siikaneva, but for Lompolojänkkä we used different $j_{\max }$ as LAI can be expected to peak earlier at the northern latitudes (Raivonen et al., 2015). The growingseason peak LAI in the eddy covariance footprint area at Siikaneva was approximately $0.4 \mathrm{~m}^{2} \mathrm{~m}^{-2}$ (Riutta et al., 2007) and $1.3 \mathrm{~m}^{2} \mathrm{~m}^{-2}$ at Lompolojänkkä (Aurela et al., 2009). We also chose to add a constant wintertime LAI in the model since it is known that a significant green sedge biomass, approximately $15 \%$ of the maximum, may overwinter (Bernard and Hankinson, 1979; Saarinen, 1998). This meant overwintering LAI of up to $0.05 \mathrm{~m}^{2} \mathrm{~m}^{-2}$ for Siikaneva and 0.195 for Lompolojänkkä. We used the same LAI for all the years.

The input anoxic respiration was created from two components: simulated NPP and temperature-dependent anoxic peat decomposition $V_{\mathrm{pR}}\left(\mathrm{mol} \mathrm{m}^{-2} \mathrm{~s}^{-1}\right)$. As methanogens seem to be keen on fresh, newly fixed carbon (Couwenberg and Fritz, 2012), such as the root exudates, many models relate the $\mathrm{CH}_{4}$ production rate directly with the NPP of the wetland vegetation (Wania et al., 2010; Walter and Heimann, 2000; Zhuang et al., 2004). We simply simulated the NPP time series for the sites, allocated the NPP vertically along the root distribution (Eq. 4), and removed the fraction that was in aerobic conditions, i.e., above the WTD (based on the measured WTD time series). The soil profile for which this was computed was $2 \mathrm{~m}$ of peat with $0.1 \mathrm{~m}$ layers. This NPP was scaled so that the output visually fitted the measured $\mathrm{CH}_{4}$ fluxes at Siikaneva using a scaling factor $f_{\mathrm{s}}$ of 0.4 .

The NPP of Siikaneva was calculated by running models of gross photosynthesis $\left(P_{\mathrm{g}}\right)$ and autotrophic respiration $(R)$. We used the $P_{\mathrm{g}}$ model for a sedge and dwarf shrub canopy by Riutta et al. (2007) (Eq. B2):

$$
\begin{aligned}
P_{\mathrm{g}} & =P_{\max } \frac{I}{h+I}\left[1-e^{-a \times \mathrm{LAI}}\right] \\
& \times e^{-0.5\left(\frac{T_{\text {air }}-T_{\mathrm{opt}}}{T_{\text {tol }}}\right)^{2}} \times e^{-0.5\left(\frac{d_{\mathrm{W}}-d_{\mathrm{W}, \mathrm{opt}}}{d_{\mathrm{W}, \mathrm{tol}}}\right)^{2}},
\end{aligned}
$$

where $P_{\mathrm{g}}$ is the $\mathrm{CO}_{2}$ uptake rate of the canopy $\left(\mathrm{mol} \mathrm{CO}_{2} \mathrm{~s}^{-1} \mathrm{~m}^{-2}\right.$ ground surface area), $P_{\max }$ is the maximum potential $\mathrm{CO}_{2}$ uptake rate $\left(\mathrm{mol} \mathrm{CO}_{2} \mathrm{~s}^{-1} \mathrm{~m}^{-2}\right.$ ground surface area), $I\left(\mu \mathrm{mol} \mathrm{m}{ }^{-2} \mathrm{~s}^{-1}\right)$ is PAR, $h\left(\mu \mathrm{mol} \mathrm{m}^{-2} \mathrm{~s}^{-1}\right)$ is PAR at which half of maximum photosynthesis is reached, $a$ is the initial slope of saturating leaf area response function, LAI is leaf area index (Eq. B1), $T_{\text {air }}\left({ }^{\circ} \mathrm{C}\right)$ is air temperature, $T_{\mathrm{opt}}\left({ }^{\circ} \mathrm{C}\right)$ is the optimal air temperature for photosynthesis, $T_{\text {tol }}\left({ }^{\circ} \mathrm{C}\right)$ is temperature tolerance, $d_{\mathrm{W}}(\mathrm{cm})$ is WTD, $d_{\mathrm{W} \text {,opt }}(\mathrm{cm})$ is the optimal WTD for photosynthesis, and $d_{\mathrm{W} \text {,tol }}(\mathrm{cm})$ is WTD tolerance. The parameter values are listed in Table B1. $R\left(\mathrm{~mol} \mathrm{CO}_{2} \mathrm{~s}^{-1} \mathrm{~m}^{-2}\right)$ was simulated with a model parameterized for sedges only (Raivonen et al., 2015) (Eq. B3):

$$
\begin{aligned}
R & =R_{\mathrm{ref}} \times \mathrm{LAI} \times e^{b\left(\frac{1}{T_{\mathrm{ref}}-T_{0}}-\frac{1}{T_{\text {air }}-T_{0}}\right)} \\
& \times e^{-0.5\left(\frac{d_{\mathrm{W}}-d_{\mathrm{W}, \mathrm{opt}}}{d_{\mathrm{W}, \mathrm{tol}}}\right)^{2}}
\end{aligned}
$$

where $R$ is the $\mathrm{CO}_{2}$ release rate of the canopy, $R_{\text {ref }}$ $\left(\mathrm{mol} \mathrm{CO} \mathrm{s}^{-1} \mathrm{~m}^{-2}\right.$ leaf area) is the $\mathrm{CO}_{2}$ release rate per unit of leaf area under reference conditions, $b(\mathrm{~K})$ is an exponen- 
Table B1. Parameter values of the models used for producing input for the Siikaneva and Lompolojänkkä runs. The value marked with * is the only one specific for the Lompolojänkkä site. The parameter value marked with $* *$ is fitted in this study, and the value $* * *$ is based on Szafranek-Nakonieczna and Stepniewska (2014); the others are from the original references of the photosynthesis and respiration models.

\begin{tabular}{|c|c|c|}
\hline Symbol & Definition & Value \\
\hline$P_{\max }$ & maximum potential $\mathrm{CO}_{2}$ uptake $\left(\mathrm{mol}(\mathrm{C}) \mathrm{s}^{-1} \mathrm{~m}^{-2}\right.$ ground area) & $1.24 x^{-5}$ \\
\hline$k$ & PAR at which half of maximum photosynthesis is reached $\left(\mu \mathrm{mol} \mathrm{m} \mathrm{m}^{-2} \mathrm{~s}^{-1}\right)$ & 223.9 \\
\hline$a$ & initial slope of saturating leaf area response function & 0.778 \\
\hline$T_{\mathrm{Opt}}$ & optimal air temperature $\left({ }^{\circ} \mathrm{C}\right)$ & 24.88 \\
\hline$T_{\text {tol }}$ & temperature tolerance $\left({ }^{\circ} \mathrm{C}\right)$ & 14.69 \\
\hline$d_{\mathrm{W}, \mathrm{opt}}$ & optimal water table depth $(\mathrm{cm})$ & -29.1 \\
\hline$d_{\mathrm{W}, \text { tol }}$ & water table depth tolerance $(\mathrm{cm})$ & 67.27 \\
\hline$R_{\text {ref }}$ & respiration rate in reference conditions $\left(\mathrm{mol}(\mathrm{C}) \mathrm{s}^{-1} \mathrm{~m}^{-2}\right.$ leaf area) & $6.94 x^{-7}$ \\
\hline$b$ & activation energy/gas constant $(\mathrm{K})$ & 300 \\
\hline$T_{\text {ref }}$ & reference temperature of autotrophic respiration $(\mathrm{K})$ & 283.15 \\
\hline$T_{0}$ & $T$ at which $R=0(\mathrm{~K})$ & 227.13 \\
\hline $\mathrm{LAI}_{\max }$ & peak LAI & 0.4 \\
\hline $\mathrm{LAI}_{\min }$ & overwintering LAI & 0.05 \\
\hline$j_{\max }$ & Julian date of the peak LAI & 209/190* \\
\hline$c$ & parameter to adjust the LAI curve shape & 0.2 \\
\hline$f_{\mathrm{s}}$ & NPP scaling factor & $0.4^{* *}$ \\
\hline$R_{\text {ref, } \mathrm{pR}}$ & reference temperature of peat respiration $(\mathrm{K})$ & 273.15 \\
\hline$Q_{10}$ & base value for temperature dependence of peat respiration & $3.5^{* * *}$ \\
\hline$\tau_{\mathrm{C}}$ & turnover time of the catotelm carbon pool $(y)$ & 30000 \\
\hline$\rho_{\mathrm{C}}$ & density of the carbon pool $\left(\mathrm{mol}(\mathrm{C}) \mathrm{m}^{-3}\right)$ & 6277.73 \\
\hline
\end{tabular}

tial parameter depicting the temperature sensitivity of respiration, $T_{\text {ref }}(\mathrm{K})$ is the reference temperature, and $T_{0}(\mathrm{~K})$ is the temperature at which respiration reaches zero (Table B1).

The daily averages of net photosynthesis $P_{\mathrm{n}}$ $\left(\mathrm{mol} \mathrm{CO}_{2} \mathrm{~s}^{-1} \mathrm{~m}^{-2}\right)$ were calculated as the difference between $P_{\mathrm{g}}$ and $R$. Photosynthetically active seasons were determined by searching for dates of snowmelt in spring or arrival of snow cover in autumn from the reflected PAR data or, in some cases, using air temperature (permanently $>5^{\circ} \mathrm{C}$ ) as the criterion. No direct measurements of $P_{\mathrm{n}}$ or vascular NPP exist for validation but the simulated $P_{\mathrm{n}}$ of the year 2005 was compared with an NPP estimate derived from eddy covariance $\mathrm{CO}_{2}$ fluxes measured that year on Siikaneva. Briefly, the estimated contributions of Sphagnum mosses (30\%; Riutta et al., 2007) and autotrophic respiration (50\%; Gifford, 1994) were subtracted from the eddy-covariancebased gross primary productivity (GPP) (Aurela et al., 2007; data obtained via personal communication), and the remains were taken as an estimate of the NPP of vascular vegetation. The two NPP estimates were well correlated (with $R^{2}$ of 0.9 ) but the eddy-covariance-based NPP was on average 1.56-fold compared with the simulated $P_{\mathrm{n}}$. Since the latter also was somewhat low compared with what has been reported for similar peatlands, the final estimate of NPP for the years 2005 to 2011 was produced by scaling the simulated $P_{\mathrm{n}}$ upwards by 1.56 .

For Lompolojänkkä, the GPP time series over the years 2006 to 2010 was available (Aurela et al., 2009); thus, we de- rived the NPP of vascular vegetation directly from the GPP data. Again, we assumed that autotrophic respiration contributes $50 \%$ to the GPP (Gifford, 1994) and the contribution of Sphagnum was estimated to be $10 \%$, based on the biomass values reported for Siikaneva and Lompolojänkkä (Li et al., 2016).

The anoxic peat respiration for both sites was computed for the peat layers below WTD using the $Q_{10}$ model for catotelm decomposition presented in Schuldt et al. (2013) (Eq. B4):

$V_{\mathrm{pR}}=\sum_{z_{\min }}^{\mathrm{WTD}} Q_{10}^{\frac{T(z)-T_{\mathrm{ref}, \mathrm{pR}}}{10}} \frac{1}{\tau_{c}} \rho_{\mathrm{C}} \mathrm{d} z$.

Here, $Q_{10}$ is the base for temperature dependence of respiration, $T_{\text {ref,pR }}$ is reference temperature for peat respiration $(\mathrm{K}), \tau_{\text {cato }}$ is turnover time of the catotelm carbon pool (s), and $\rho_{\mathrm{C}}\left(\mathrm{mol}(\mathrm{C}) \mathrm{m}^{-3}\right)$ is the density of the carbon pool. The parameter values were taken from Schuldt et al. (2013), except for the $Q_{10}$ where we used a higher value of 3.5, which was the average $Q_{10}$ found by Szafranek-Nakonieczna and Stepniewska (2014) (Table B1). 


\section{The Supplement related to this article is available online at https://doi.org/10.5194/gmd-10-4665-2017- supplement.}

Author contributions. SS and LB developed the model. MR participated in model development and designed and carried out the tests with contribution from LB, JS, TA, TM, JM, and TV. MT, XL, MH, SS, TK, and VB contributed to the model development. JR, OP, MA, and AL provided observational data from the Siikaneva and Lompolojänkkä sites. TL, SJ, and EST provided knowledge and advice about peatland methane processes for model development. MR prepared the manuscript with contributions from all co-authors.

Competing interests. The authors declare that they have no conflict of interest.

Acknowledgements. We thank the Academy of Finland Centre of Excellence (272041), Academy Professor projects (284701 and 282842), CARB-ARC (285630), ICOS Finland (281255), NCoE eSTICC (57001), EU-H2020 CRESCENDO (641816), and MONIMET (LIFE12 ENV/FI/000409), and the Maj and Tor Nessling Foundation (projects 2008336, 2009067, and 2010212) for support. The Academy of Finland is also acknowledged by Eeva-Stiina Tuittila (project 287039) and Tuula Larmola (121535, 286731, and 293365). Thomas Kleinen acknowledges funding by the German Federal Ministry of Education and Research (BMBF) in projects CarboPerm and PalMod.

Edited by: Jason Williams

Reviewed by: three anonymous referees

\section{References}

Arah, J. R. M. and Stephen, K. D.: A model of the processes leading to methane emission from peatland - kinetics of $\mathrm{CH}_{4}$ and $\mathrm{O}_{2}$ removal and the role of plant roots, Atmos. Environ., 32, 32573264, 1998.

Aubinet, M., Grelle, A., Ibrom, A., Rannik, Ü., Moncrieff, J., Foken, T., Kowalski, A. S., Martin, P. H., Berbigier, P., Bernhofer, Ch., Clement, R., Elbers, J., Granier, A., Grünwald, T., Morgernstern, K., Pilegaard, K., Rebmann, C., Snijders, W., Valentini, R., and Vesala, T.: Estimates of the annual net carbon and water exchange of European forests: the EUROFLUX methodology, Adv. Ecol. Res., 30, 113-175, 2000.

Aurela, M., Riutta, T., Laurila, T., Tuovinen, J.-P., Vesala, T., Tuittila, E.-S., Rinne, J., Haapanala, S., and Laine, J.: $\mathrm{CO}_{2}$ exchange of a sedge fen in southern Finland - the impact of a drought period, Tellus B, 59, 826-837, 2007.

Aurela, M., Lohila, A., Tuovinen, J.-P., Hatakka, J., Riutta, T., and Laurila, T.: Carbon dioxide exchange on a northern boreal fen, Boreal Environ. Res., 14, 699-710, 2009.

Baird, A. J., Beckwith, C. W., and Waldron, S.: Ebullition of methane-containing gas bubbles from near- surface Sphagnum peat, Geophys. Res. Lett., 31, L21505, https://doi.org/10.1029/2004GL021157, 2004.

Bergman, I., Lundberg, P., and Nilsson, M.: Microbial carbon mineralization in an acid surface peat: effects of environmental factors in laboratory incubations, Soil Biol. Biochem., 31, 18671877, 1999.

Bernard, J. M. and Hankinson, G.: Seasonal changes in standing crop, primary production, and nutrient levels in a Carex rostrata wetland, Oikos, 32, 328-336, 1979.

Berrittella, C. and van Huissteden, J.: Uncertainties in modelling $\mathrm{CH}_{4}$ emissions from northern wetlands in glacial climates: effect of hydrological model and $\mathrm{CH}_{4}$ model structure, Clim. Past, 5, 361-373, https://doi.org/10.5194/cp-5-361-2009, 2009.

Berrittella, C. and van Huissteden, J.: Uncertainties in modelling $\mathrm{CH} 4$ emissions from northern wetlands in glacial climates: the role of vegetation parameters, Clim. Past, 7, 1075-1087, https://doi.org/10.5194/cp-7-1075-2011, 2011.

Bird, R. B., Stewart, W. E., and Lightfoot, E. N.: Transport Phenomena, John Wiley and Sons, New York, USA, 1960.

Bon, C. E., Reeve, A. S., Slater, L., and Comas, X.: Using hydrologic measurements to investigate free-phase gas ebullition in a Maine peatland, USA, Hydrol. Earth Syst. Sci., 18, 953-965, https://doi.org/10.5194/hess-18-953-2014, 2014.

Bridgham, S. D., Cadillo-Quiroz, H., Keller, J. K., and Zhuang, Q.: Methane emissions from wetlands: biogeochemical, microbial and modelling perspectives from local to global scales, Glob. Change Biol., 9, 1325-1346. https://doi.org/10.1111/gcb.12131, 2013.

Brix, H., Sorrell, B. K., and Schierup, H. H.: Gas fluxes achieved by in-situ convective flow in Phragmites australis, Aquat. Bot., 54, 2-3, 151-163, 1996.

Brix, H. and Sorrell, B. K.: Gas transport and exchange through wetland plant aerenchyma, in: Methods in Biogeochemistry of Wetlands, edited by: DeLaune, R. D., Reddy, K. R., Richardson, C. J., and Megonigal, J. P., SSSA Book Series no. 10, Soil Science Society of America, Madison, USA, 177-196, 2013.

Budishchev, A., Mi, Y., van Huissteden, J., Belelli-Marchesini, L., Schaepman-Strub, G., Parmentier, F. J. W., Fratini, G., Gallagher, A., Maximov, T. C., and Dolman, A. J.: Evaluation of a plotscale methane emission model using eddy covariance observations and footprint modelling, Biogeosciences, 11, 4651-4664, https://doi.org/10.5194/bg-11-4651-2014, 2014.

Celis-García, M. L. B., Ramírez, F., Revah, S., Razo-Flores, E., and Monroy, O.: Sulphide and oxygen inhibition over the anaerobic digestion of organic matter: influence of microbial immobilization type, Environ. Technol., 25, 1265-1275, 2004.

Chanton, J. P. and Whiting, G. J.: Methane stable isotopic distributions as indicators of gas transport mechanisms in emergent aquatic plants, Aquat. Bot., 54, 227-236, 1993.

Ciais, P., Sabine, C., Bala, G., Bopp, L., Brovkin, V., Canadell, J., Chhabra, A., DeFries, R., Galloway, J., Heimann, M., Jones, C., Le Quéré, C., Myneni, R. B., Piao, S., and Thornton, P.: Carbon and Other Biogeochemical Cycles, in: Climate Change 2013: The Physical Science Basis. Contribution of Working Group I to the Fifth Assessment Report of the Intergovernmental Panel on Climate Change, edited by: Stocker, T. F., Qin, D., Plattner, G.K., Tignor, M., Allen, S. K., Boschung, J., Nauels, A., Xia, Y., Bex, V., and Midgley, P. M., Cambridge University Press, Cambridge, United Kingdom and New York, NY, USA, 2013. 
Clark, D. B., Mercado, L. M., Sitch, S., Jones, C. D., Gedney, N., Best, M. J., Pryor, M., Rooney, G. G., Essery, R. L. H., Blyth, E., Boucher, O., Harding, R. J., Huntingford, C., and Cox, P. M.: The Joint UK Land Environment Simulator (JULES), model description - Part 2: Carbon fluxes and vegetation dynamics, Geosci. Model Dev., 4, 701-722, https://doi.org/10.5194/gmd-4701-2011, 2011.

Collin, M. and Rasmuson, A.: A comparison of gas diffusivity models for unsaturated porous media, Soil Sci. Soc. Am. J., 52, 15591565, 1988.

Colmer, T. D.: Long-distance transport of gases in plants: a perspective on internal aeration and radial oxygen loss from roots, Plant Cell Environ., 26, 17-36, 2003.

Comas, X., Slater, S., and Reeve, A. S.: Atmospheric pressure drives changes in the vertical distribution of biogenic free-phase gas in a northern peatland, J. Geophys. Res., 116, G04014, https://doi.org/10.1029/2011JG001701, 2011.

Coulthard, T. J., Baird, A. J., Ramirez, J., and Waddington, J. M.: Methane dynamics in peat: importance of shallow peats and a novel reduced-complexity approach for modeling ebullition, in: Geophysical Monograph Series, Carbon Cycling in Northern Peatlands, 184, 173, https://doi.org/10.1029/2008GM000811, 2009.

Couwenberg, J. and Fritz, C.: Towards developing IPCC methane "emission factors" for peatlands (organic soils), Mires Peat, 10, $1-17,2012$.

Cresto Aleina, F., Runkle, B. R. K., Kleinen, T., Kutzbach, L., Schneider, J., and Brovkin, V.: Modeling micro-topographic controls on boreal peatland hydrology and methane fluxes, Biogeosciences, 12, 5689-5704, https://doi.org/10.5194/bg-12-56892015, 2015.

Drebs, A., Nordlund, A., Karlsson, P., Helminen, J., and Rissanen, P.: Climatological statistics of Finland 1971-2000, Finnish Meteorological Institute, Helsinki, 99, ISBN-10: 951-697-568-2, 2002.

Dunfield, P., Knowles, R., Dumont, R., and Moore, T. R.: Methane production and consumption in temperate and subarctic peat soils: Response to temperature and $\mathrm{pH}$, Soil Biol. Biochem., 25, 321-326, 1993.

Ekici, A., Beer, C., Hagemann, S., Boike, J., Langer, M., and Hauck, C.: Simulating high-latitude permafrost regions by the JSBACH terrestrial ecosystem model, Geosci. Model Dev., 7, 631-647, https://doi.org/10.5194/gmd-7-631-2014, 2014.

Estop-Aragonés, C., Klaus-Holger, K., and Blodau, C.: Controls on in situ oxygen and dissolved inorganic carbon dynamics in peats of a temperate fen, J. Geophys. Res., 117, G02002, https://doi.org/10.1029/2011JG001888, 2012.

Fan, Z., Neff, J. C., Waldrop, M. P., Ballantyne, A. P., and Turetsky, M. R.: Transport of oxygen in soil pore-water systems: implications for modeling emissions of carbon dioxide and methane from peatlands, Biogeochemistry, 121, 455-470, 2014.

Fritz, C., Pancotto, V. A., Elzenga, J. T. M., Visser, E. J. W., Grootjans, A. P., Pol, A., Iturraspe, R., Roelofs, J. G. M., and Smolders, A. J. P.: Zero methane emission bogs: extreme rhizosphere oxygenation by cushion plants in Patagonia, New Phytol., 190, 398-408, 2011

Gifford, R. M.: The global carbon cycle: a viewpoint on the missing sink, Aust. J. Plant Physiol., 21, 1-15, 1994.
Glaser, P. H., Chanton, J. P., Morin, P., Rosenberry, D. O., Siegel, D. I., Ruud, O., Chasar, L. I., and Reeve, A. S.: Surface deformations as indicators of deep ebullition fluxes in a large northern peatland, Global Biogeochem. Cy., 18, GB1003, https://doi.org/10.1029/2003GB002069, 2004.

Grant, R. F. and Roulet, N. T.: Methane efflux from boreal wetlands: Theory and testing of the ecosystem model Ecosys with chamber and tower flux measurements, Global Biogeochem. Cy., 16, 1054, https://doi.org/10.1029/2001GB001702, 2002.

Grant, R. F., Humphreys, E. R., and Lafleur, P. M.: Ecosystem $\mathrm{CO}_{2}$ and $\mathrm{CH}_{4}$ exchange in a mixed tundra and a fen within a hydrologically diverse arctic landscape: 1 . Modeling versus measurements, J. Geophys. Res.-Biogeo., 120, 1366-1387, 2015.

Green, S. M. and Baird, A. J.: A mesocosm study of the role of the sedge Eriophorum angustifolium in the efflux of methane including that due to episodic ebullition - from peatlands, Plant Soil, 351, 207-218, 2012.

Hari, P. and Kulmala, M.: Station for Measuring EcosystemAtmosphere Relations (SMEAR II), Boreal Environ. Res., 10, 315-322, 2005.

Hennenberg, A., Sorrell, B. K., and Brix H.: Internal methane transport through Juncus effusus: experimental manipulation of morphological barriers to test above- and below-ground diffusion limitation, New Phytol., 196, 799-806, 2012.

Iiyama, I. and Hasegawa, S.: Gas diffusion coefficient of undisturbed peat soils, Soil Sci. Plant Nutr., 51, 431-435, 2005.

Iiyama, I., Ozawa, K., and Nagata, O.: Soil $\mathrm{O}_{2}$ profile affected by gas diffusivity and water retention in a drained peat layer, Soils Found., 52, 49-58, 2012.

Ito, A. and Inatomi, M.: Use of a process-based model for assessing the methane budgets of global terrestrial ecosystems and evaluation of uncertainty, Biogeosciences, 9, 759-773, https://doi.org/10.5194/bg-9-759-2012, 2012.

Jackowicz-Korczyński, M., Christensen, T. R., Bäckstrand, K., Crill, P., Friborg, T., Mastepanov, M., and Ström, L.: Annual cycle of methane emission from a subarctic peatland, J. Geophys. Res.-Biogeo., 115, https://doi.org/10.1029/2008JG000913, 2010.

Juutinen, S., Alm, J., Larmola, T., Saarnio, S., Martikainen, P. J., and Silvola J.: Stand-specific diurnal dynamics of $\mathrm{CH}_{4}$ fluxes in boreal lakes: Patterns and controls, J. Geophys. Res., 109, D19313, https://doi.org/10.1029/2004JD004782, 2004.

Kaiser, S., Göckede, M., Castro-Morales, K., Knoblauch, C., Ekici, A., Kleinen, T., Zubrzycki, S., Sachs, T., Wille, C., and Beer, C.: Process-based modelling of the methane balance in periglacial landscapes (JSBACH-methane), Geosci. Model Dev., 10, 333 358, https://doi.org/10.5194/gmd-10-333-2017, 2017.

Kelker, D. and Chanton, J.: The effect of clipping on methane emissions from Carex, Biogeochemistry, 39, 37-44, https://doi.org/10.1023/A:1005866403120, 1997.

Kellner, E., Baird, A. J., Oosterwoud, M., Harrison, K., and Waddington, J. M.: Effect of temperature and atmospheric pressure on methane $\left(\mathrm{CH}_{4}\right)$ ebullition from near-surface peats, Geophys. Res. Lett., 33, L18405, https://doi.org/10.1029/2006GL027509, 2006.

Khvorostyanov, D. V., Krinner, G., Ciais, P., Heimann, M., and Zimov, S. A.: Vulnerability of permafrost carbon to global warming. Part I: model description and role of heat generated by organic matter decomposition, Tellus B, 60, 250-264, 2008. 
King, G. M.: Associations of methanotrophs with the roots and rhizomes of aquatic vegetation, Appl. Environ. Microb., 60, 32203227, 1994.

King, J. Y., Reeburgh, W. S., and Regli, S. K.: Methane emission and transport by arctic sedges in Alaska: Results of a vegetation removeal experiment, J. Geophys. Res., 103, 29083-29092, 1998.

Lai, D. Y. F.: Methane dynamics in northern peatlands: a review, Pedosphere, 19, 409-421, 2009.

Li, T., Raivonen, M., Alekseychick, P., Aurela, M., Lohila, A., Zheng, X., Zhang, Q., Wang, G., Mammarella, I., Rinne, J., Yu, L., Xie, B., Vesala, T., and Zhang, W.: Importance of vegetation classes in modeling $\mathrm{CH}_{4}$ emissions from boreal and subarctic wetlands in Finland, Sci. Total Environ., 572, 1111-1122, 2016.

Lloyd, J. and Taylor, J. A.: On the temperature dependence of soil respiration, Funct. Ecol., 8, 315-323, 1994.

Macdonald, J. A., Fowler, D., Hargreaves, K. J., Skiba, U., Leith, I. D., and Murray, M. B.: Methane emission rates from a northern wetland; response to temperature, water table and transport, Atmos. Environ., 32, 3219-3227, 1998.

Mainiero, R. and Kazda, M.: Effects of Carex rostrata on soil oxygen in relation to soil moisture, Plant Soil, 270, 311-320, 2004.

Mammarella, I., Launiainen, S., Gronholm, T., Keronen, P., Pumpanen, J., Rannik, Ü., and Vesala, T.: Relative humidity effect on the high-frequency attenuation of water vapor flux measured by a closed-path eddy covariance system, J. Atmos. Ocean. Technol., 26, 1856-1866, 2009.

Mammarella, I., Peltola, O., Nordbo, A., Järvi, L., and Rannik, Ü.: Quantifying the uncertainty of eddy covariance fluxes due to the use of different software packages and combinations of processing steps in two contrasting ecosystems, Atmos. Meas. Tech., 9, 4915-4933, https://doi.org/10.5194/amt-9-4915-2016, 2016.

McMillen, R. T.: An eddy correlation technique with extended applicability to non-simple terrain, Bound.-Lay. Meteorol., 43, 231-245, 1988.

Melton, J. R., Wania, R., Hodson, E. L., Poulter, B., Ringeval, B., Spahni, R., Bohn, T., Avis, C. A., Beerling, D. J., Chen, G., Eliseev, A. V., Denisov, S. N., Hopcroft, P. O., Lettenmaier, D. P., Riley, W. J., Singarayer, J. S., Subin, Z. M., Tian, H., Zürcher, S., Brovkin, V., van Bodegom, P. M., Kleinen, T., Yu, Z. C., and Kaplan, J. O.: Present state of global wetland extent and wetland methane modelling: conclusions from a model intercomparison project (WETCHIMP), Biogeosciences, 10, 753788, https://doi.org/10.5194/bg-10-753-2013, 2013.

Mikkelä, C., Sundh, I., Svensson, B. H., and Nilsson, M.: Diurnal variation in methane emission in relation to the water table, soil temperature, climate and vegetation cover in a Swedish acid mire, Biogeochemistry, 28, 93-114, 1995.

Millington, R. J.: Gas diffusion in porous media, Science, 130, 100$102,1959$.

Millington, R. J. and Quirk, J. P.: Permeability of porous solids, Trans. Faraday Soc., 57, 1200-1207, 1961.

Mitsch, W. J. and Gosselink, J. G.: Wetlands, John Wiley \& Sons, New Jersey, USA, 582 pp., 2007.

Moog, P. R. and Brüggeman, W.: Flooding tolerance of Carex species. II. Root gas-exchange capacity, Planta, 207, 199-206, 1998.

Moore, T. R., DeYoung, A., Bubier, J. L., Humphreys, E. R., Lafleur, P. M., and Roulet, N. T.: A multi-year record of methane flux at the Mer Bleue Bog, southern Canada, Ecosystems, 14, 646-657, 2011.

Morrissey, L. A., Zobel, D. B., and Livingston, G. P.: Significance of stomatal control on methane release from Carex-dominated wetlands, Chemosphere, 26, 339-355, 1993.

Myhre, G., Shindell, D., Bréon, F.-M., Collins, W., Fuglestvedt, J., Huang, J., Koch, D., Lamarque, J.-F., Lee, D., Mendoza, B., Nakajima, T., Robock, A., Stephens, G., Takemura, T., and Zhang, H.: Anthropogenic and Natural Radiative Forcing, in: Climate Change 2013: The physical Science Basis. Contribution of Working Group I to the Fifth Assessment Report of the Intergovernmental Panel on Climate Change, edited by: Stocker, T. F., Qin, D., Plattner, G.-K., Tignor, M., Allen, S. K., Boschung, J., Nauels, A., Xia, Y., Bex, V., and Midgley, P. M., Cambridge University Press, Cambridge, United Kingdom and New York, NY, USA, 2013.

Nilsson, M. and Öquist, M.: Partitioning litter mass loss into carbon dioxide and methane in peatland ecosystems, Geoph. Monog. Series, Carbon Cycling in Northern Peatlands, 184, 131-144, 2009.

Nouchi, I., Mariko, S., and Aoki, K.: Mechanism of methane transport from the rhizoshphere to the atmospher through rice plants, Plant Physiol., 94, 59-66, 1990.

Oikawa, P. Y., Jenerette, G. D., Knox, S. H., Sturtevant, C., Verfaillie, J., Dronova, L., Poindexter, C. M. Eichelmann, E., and Baldocchi, D. D.: Evaluation of a hierarchy of models reveals importance of substrate limitation for predicting carbon dioxide and methane exchange in restored wetlands, J. Geophys. Res.Biogeo., 122, 145-167, https://doi.org/10.1002/2016JG003438, 2017.

Peltola, O., Raivonen, M., Li, X., and Vesala, T.: Technical Note: Comparison of methane ebullition modelling approaches used in terrestrial wetland models, Biogeosciences Discuss., https://doi.org/10.5194/bg-2017-274, in review, 2017.

Poorter, H. and De Jong, R.: A comparison of specific leaf area, chemical composition and leaf construction costs of field plants from 15 habitats differing in productivity, New Phytol., 143, 163-176, 1999.

Popp, T. J., Chanton, J. P., Whiting, G. J., and Grant, N.: Methane stable isotope distribution at a Carex dominated fen in North Central Alberta, Global Biogeochem. Cy., 13, 1063-1077, 1999.

Raivonen, M., Mäkiranta, P., Lohila, A., Juutinen, S., Vesala, T., and Tuittila, E.-S.: A simple $\mathrm{CO}_{2}$ exchange model simulates the seasonal leaf area development of peatland sedges, Ecol. Model., 314, 32-43, 2015.

Ramirez, J. A., Baird, A. J., Coulthard, T. J., and Waddington, M.: Ebullition of methane from peatlands: Does peat act as a signal shredder?, Geophys. Res. Lett., 42, 3371-3379, 2015.

Rannik, Ü., Vesala, T., and Keskinen, R.: On the damping of temperature fluctuations in a circular tube relevant to the eddy covariance measurement technique, J. Geophys. Res., 102, 12789 12794, 1997.

Reiche, M., Gleixner, G., and Küsel, K.: Effect of peat quality on microbial greenhouse gas formation in an acidic fen, Biogeosciences, 7, 187-198, https://doi.org/10.5194/bg-7-1872010, 2010.

Reid, M. C., Pal, D. S., and Jaffé, P. R.: Dissolved gas dynamics in wetland soils: root-mediated gas transfer kinetics determined via push-pull tracer tests, Water Resour. Res., 51, 7343-7357, 2015. 
Rezanezhad, F., Price, J. S., Quinton, W. L., Lennartz, B., Milojevic, T., and Van Cappellen, P.: Structure of peat soils and implications for water storage, flow and solute transport: A review update for geochemists, Chem. Geol., 429, 75-84, 2016.

Riley, W. J., Subin, Z. M., Lawrence, D. M., Swenson, S. C., Torn, M. S., Meng, L., Mahowald, N. M., and Hess, P.: Barriers to predicting changes in global terrestrial methane fluxes: analyses using CLM4Me, a methane biogeochemistry model integrated in CESM, Biogeosciences, 8, 1925-1953, https://doi.org/10.5194/bg-8-1925-2011, 2011

Ringeval, B., Friedlingstein, P., Koven, C., Ciais, P., de NobletDucoudré, N., Decharme, B., and Cadule, P.: Climate$\mathrm{CH}_{4}$ feedback from wetlands and its interaction with the climate- $\mathrm{CO}_{2}$ feedback, Biogeosciences, 8, 2137-2157, https://doi.org/10.5194/bg-8-2137-2011, 2011

Rinne, J., Riutta, T., Pihlatie, M., Aurela, M., Haapanala, S., Tuovinen, J. P., Tuittila, E.-S., and Vesala, T.: Annual cycle of methane emission from a boreal fen measured by the eddy covariance technique, Tellus B, 59, 449-457, 2007.

Riutta, T., Laine, J., and Tuittila, E.-S.: Sensitivity of $\mathrm{CO}_{2}$ exchange of fen ecosystem components to water level variation, Ecosystems, 10, 718-733, https://doi.org/10.1007/s10021-007-9046-7, 2007.

Saarinen, T.: Biomass and production of two vascular plants in a boreal mesotrophic fen, Can. J. Bot., 74, 934-938, 1996.

Saarinen, T.: Demography of Carex rostrata in boreal mesotrophic fen: shoot dynamics and biomass development, Ann. Bot. Fennici, 35, 203-209, 1998.

Sander, R.: Compilation of Henry's law constants (version 4.0) for water as solvent, Atmos. Chem. Phys., 15, 4399-4981, https://doi.org/10.5194/acp-15-4399-2015, 2015.

Scanlon, D. and Moore, T.: Carbon dioxide production from peatland soil profiles: the influence of temperature, oxic/anoxic conditions and substrate, Soil Sci., 165, 153-160, 2000.

Schimel, J. P.: Plant transport and methane production as controls on methane flux from arctic wet meadow tundra, Biogeochemistry, 28, 183-200, 1995.

Schuldt, R. J., Brovkin, V., Kleinen, T., and Winderlich, J.: Modelling Holocene carbon accumulation and methane emissions of boreal wetlands - an Earth system model approach, Biogeosciences, 10, 1659-1674, https://doi.org/10.5194/bg-10-16592013, 2013.

Segers, R.: Methane production and methane consumption: a review of processes underlying wetland methane fluxes, Biogeochemistry, 41, 23-51, 1998.

Segers, R. and Leffelaar, P. A.: Modeling methane fluxes in wetlands with gas-transporting plants 1 . Single-root scale, J. Geophys. Res.-Atmos., 106, 3511-3528, 2001a.

Segers, R. and Leffelaar, P. A.: Modeling methane fluxes in wetlands with gas-transporting plants 2 . Soil layer scale, J. Geophys. Res.-Atmos., 106, 3529-3540, 2001 b.

Segers, R. and Leffelaar, P. A.: Modeling methane fluxes in wetlands with gas-transporting plants 3. Plot scale, J. Geophys. Res.Atmos., 106, 3541-3558, 2001c.

Shaver, G. R. and Cutler, J. C.: The vertical distribution of live vascular phytomass in cottongrass tussock tundra, Arctic Alpine Res., 11, 335-342, 1979.
Silins, U. and Rothwell, R. L.: Spatial patterns of aerobic limit depth and oxygen diffusion rate at two peatlands drained for forestry in Alberta, Can. J. For. Res., 29, 53-61, 1999.

Slevin, D., Tett, S. F. B., and Williams, M.: Multi-site evaluation of the JULES land surface model using global and local data, Geosci. Model Dev., 8, 295-316, https://doi.org/10.5194/gmd-8295-2015, 2015.

Staunton, S.: Diffusion Processes, in: Encyclopedia of Soil Science, edited by: Chesworth, W., Springer Netherlands, 185-191, https://doi.org/10.1007/978-1-4020-3995-9_158, 2008.

Stephen, K. D., Arah, J. R. M., Daulat, N., and Clymo, R. S.: Rootmediated gas transport in peat determined by Argon diffusion, Soil Biol. Biochem., Vol 30, 501-508, 1998.

Susiluoto, J., Raivonen, M., Backman, L., Laine, M., Mäkelä, J., Peltola, O., Vesala, T., and Aalto, T.: Calibrating a wetland methane emission model with hierarchical modeling and adaptive MCMC, Geosci. Model Dev. Discuss., https://doi.org/10.5194/gmd-2017-66, in review, 2017.

Szafranek-Nakonieczna, A. and Stepniewska, Z.: Aerobic and anaerobic respiration in profiles of Polesie Lubelskie peatlands, Int. Agrophys., 28, 219-229, 2014.

Tang, J., Zhuang, Q., Shannon, R. D., and White, J. R.: Quantifying wetland methane emissions with process-based models of different complexities, Biogeosciences, 7, 3817-3837, https://doi.org/10.5194/bg-7-3817-2010, 2010.

Thomas, K. L., Benstead, J., Davies, K. L., and Lloyd, D.: Role of wetland plants in the diurnal control of $\mathrm{CH}_{4}$ and $\mathrm{CO}_{2}$ fluxes in peat, Soil Biol. Biochem., 28, 17-23, 1996.

Tokida, T., Miyazaki, T., and Mizoguchi, M.: Ebullition of methane from peat with falling atmospheric pressure, Geophys. Res. Lett., 3232, L13823, https://doi.org/10.1029/2005GL022949, 2005.

Tokida, T., Miyazaki, T., Mizoguchi, M., Nagata, O., Takakai, F., Kagemoto, A., and Hatano, R.: Falling atmospheric pressure as a trigger for methane ebullition from peatland, Global Biogeochem. Cy., 21, GB2003, https://doi.org/10.1029/2006GB002790, 2007.

Turetsky, M. R., Kotowska, A., Bubier, J., Dise, N. B., Crill, P., Hornibrook E. R. C., Minkkinen, K., Moore, T. R., Myers-Smith, I. H., Nykänen, H., Olefeldt, D., Rinne, J., Saarnio, S., Shurpali, N., Tuittila, E-S., Waddington, J. M., White, J. R., Wickland, K. P., and Wilmking, M.: A synthesis of methane emissions from 71 northern, temperate, and subtropical wetlands, Glob. Change Biol., 20, 2183-2197, 2014.

Turunen, J., Tomppo, E., Tolonen, K., and Reinikainen, A.: Estimating carbon accumulation rates of undrained mires in Finland - application to boreal and subarctic regions, The Holocene, 12, 69-80, 2002.

Valentine, D. W., Holland, E. A., and Schimel, D. S.: Ecosystem and physiological controls over methane production in northern wetlands, J. Geophys. Res., 99, 1563-1571, 1994.

van Huissteden, J., Petrescu, A. M. R., Hendriks, D. M. D., and Rebel, K. T.: Sensitivity analysis of a wetland methane emission model based on temperate and arctic wetland sites, Biogeosciences, 6, 3035-3051, https://doi.org/10.5194/bg-6-30352009, 2009.

Vile, D., Garnier, E., Shipley, B., Laurent, G., Navas, M.-L., Roumet, C., Lavorel, S., Díaz, S., Hodgson, J. G., Lloret, F., Midgley, G. F., Poorter, H., Rutherford, H., Wilson, P. J., and 
Wright, I. J.: Specific leaf area and dry matter content estimate thickness in laminar leaves, Ann. Bot., 96, 1129-1136, 2005.

Waddington, J. M., Roulet, N. T., and Swanson, R. V.: Water table control of $\mathrm{CH}_{4}$ emission enhancement by vascular plants in boreal peatlands, J. Geophys. Res.-Atmos., 101, 22775-22785, 1996.

Waddington, J. M., Harrison, K., Kellner, E., and Baird, A. J.: Effect of atmospheric pressure and temperature on entrapped gas content in peat, Hydrol. Process., 23, 2970-2980, https://doi.org/10.1002/hyp.7412, 2009.

Walter, B. P., Heimann, M., Shannon, R. D., and White, J. R.: A process-based model to derive methane emissions from natural wetlands, Geophys. Res. Lett., 23, 3731-3734, 1996.

Walter, B. and Heimann, M.: A process-based climate-sensitive model to derive methane emissions from natural wetlands: Application to five wetland sites, sensitivity to model parameters, and climate, Global Biogeochem. Cy., 14, 745-765, 2000.

Wania, R., Ross, I., and Prentice, I. C.: Implementation and evaluation of a new methane model within a dynamic global vegetation model: LPJ-WHyMe v1.3.1, Geosci. Model Dev., 3, 565-584, https://doi.org/10.5194/gmd-3-565-2010, 2010.

Watson, A., Stephen, K. D., Nedwell, D. B., and Arah, J. R. M.: Oxidation of methane in peat: Kinetics of $\mathrm{CH}_{4}$ and $\mathrm{O}_{2}$ removal and the role of plant roots, Soil Biol. Biochem., 29, 1257-1267, 1997.

Webb, E. K., Pearman, G. I., and Leuning, R.: Correction of flux measurements for density effects due to heat and water vapour transfer, Q. J. Roy. Meteor. Soc., 106, 85-100, 1980.

Whalen, S. C.: Biogeochemistry of methane exchange between natural wetlands and the atmosphere, Environ. Eng. Sci., 22, 73-94, 2005.

Whalen, S. C. and Reeburgh, W. S.: Moisture and temperature sensitivity of $\mathrm{CH}_{4}$ oxidation in boreal soils, Soil Biol. Biochem., 28, 1271-1281, 1996.
Whiting, G. J. and Chanton, J. P.: Primary production control of methane emssion from wetlands, Nature, 364, 794-795, 1993.

Wilson, D., Alm, J., Riutta, T., Laine, J., Byrne, K. A., Farrell, E. P., and Tuittila, E.-S.: A high resolution green area index for modelling the seasonal dynamics of $\mathrm{CO}_{2}$ exchange in peatland vascular plant communities, Plant Ecol., 190, 37-51, 2007.

Xu, X., Jaffe, P. R., and Mauzerall, D. L.: A process-based model for methane emission from flooded rice paddy systems, Ecol Model., 205, 475-491, 2007.

Xu, X., Schimel, J. P., Thornton, P. E., Song, X., Yuan, F., and Goswami, S.: Substrate and environmental controls on microbial assimilation of soil organic carbon: a framework for Earth system models, Ecol. Lett., 17, 547-555, 2014.

Xu, X., Yuan, F., Hanson, P. J., Wullschleger, S. D., Thornton, P. E., Riley, W. J., Song, X., Graham, D. E., Song, C., and Tian, H.: Reviews and syntheses: Four decades of modeling methane cycling in terrestrial ecosystems, Biogeosciences, 13, 3735-3755, https://doi.org/10.5194/bg-13-3735-2016, 2016.

Zhu, Q., Liu, J., Peng, C., Chen, H., Fang, X., Jiang, H., Yang, G., Zhu, D., Wang, W., and Zhou, X.: Modelling methane emissions from natural wetlands by development and application of the TRIPLEX-GHG model, Geosci. Model Dev., 7, 981-999, https://doi.org/10.5194/gmd-7-981-2014, 2014.

Zhuang, Q., Melillo, J. M., Kicklighter, D. W., Prinn, R. G., McGuire, A. D., Steudler, P. A., Felzer, B. S., and Hu, S.: Methane fluxes between terrestrial ecosystems and the atmosphere at northern high latitudes during the past century: A retrospective analysis with a process-based biogeochemistry model, Global Biogeochem. Cy., 18, GB3010, https://doi.org/10.1029/2004GB002239, 2004. 